\title{
The Design and the Construction of the Traditional Arabic Lexicons Corpus (The TAL-Corpus)
}

\author{
Majdi Sawalha ${ }^{1}$ \\ ${ }^{1}$ Department of Computer Information Systems, King Abdullah II School for Information Technology, The \\ University of Jordan, Amman, Jordan. E-mail: sawalha.majdi@ju.edu.jo \\ Correspondence: Majdi Sawalha, Department of Computer Information Systems, King Abdullah II School for \\ Information Technology, The University of Jordan, Amman, 11942, Jordan. E-mail: sawalha.majdi@ju.edu.jo
}

Received: Oct. 20, 2018

Accepted: Nov. 28, 2018

Online Published: January 9, 2019

doi:10.5539/mas.v13n2p95

URL: https://doi.org/10.5539/mas.v13n2p95

\begin{abstract}
Arabic lexicography is a well-established and deep-rooted art of Arabic literature. Computational lexicography, invests computational and storage powers of modern computers, to accelerate long-term efforts in lexicographic projects. A collection of 23 machine-readable dictionaries, which are freely available on the web, were used to build the Corpus of Traditional Arabic lexicons (the TAL-Corpus). The purpose for constructing the TAL-Corpus is to collect and organize well-established and long traditions of traditional Arabic lexicons which can also be used to create new corpus-based Arabic dictionaries.

The compilation of the TAL-Corpus followed standard design and development criteria that informed major decisions for corpus creation. The corpus building process involved extracting information from disparate formats and merging traditional Arabic lexicons. As a result, the TAL-Corpus contains more than 14 million words and over 2 million word types (different words).

The TAL-Copus was applied to create useful morphological database. This database was automatically constructed using a new algorithm which is informed by Arabic linguistics theory. The newly developed algorithm processed the text of the TAL-Corpus and as result it extracted 2781796 entries. These entries were stored in the morphological database where each represents a word-root pair (i.e. an Arabic word and its root).

A comparative evaluation of the TAL-Corpus and other three Arabic corpora showed that the lexical diversity of its vocabulary scored higher. Moreover, its coverage was computed by comparing words and lemmas against their equivalents of other corpora where it scored about $67 \%$ when comparing words and $82 \%$ when comparing lemmas.
\end{abstract}

Keywords: lexicography, traditional Arabic lexicon, corpora, dictionary building, the TAL-Corpus

\section{Introduction}

Lexicography is the applied part of lexicology. It is concerned with the design and construction of lexicons. Lexicography defines the process of collating, ordering of entries, derivations and their meaning, depending on the aim of the lexicon to be constructed and its size. Lexicography is defined as "...the branch of applied linguistics concerned with the design and construction of lexica for practical use." (Eynde \& Gibbon 2000). Moreover, lexicology is also defined as "...the branch of descriptive linguistics concerned with the linguistic theory and methodology for describing lexical information, often focusing specifically on issues of meaning." (Eynde \& Gibbon 2000). Long-term efforts in lexicographic projects have been greatly accelerated since the advent and use of computers: which is known as computational lexicography. However, constructing a large-scale broad-coverage lexicon involves time-consuming development of specifications, design, collection of lexical data, information structuring, and user-oriented presentation formatting (Eynde \& Gibbon 2000).

Corpora have been used to construct dictionaries since the release of the Collins-Birmingham University International Database COBUILD. Computer technology was used in the four stages of constructing COBUILD: data-collection, entry-selection, entry construction and entry-arrangement (Ooi 1998). Similarly, the Oxford English Corpus was created to construct the Oxford English Dictionaries. It consists of 2.5 billion words of $21^{\text {st }}$ century English which provides evidences of language use and development. It also draws an accurate picture of the language today. It contains text from literary, novels, specialist journals, everyday newspapers, magazines, blogs, emails, and Internet message boards. These texts were collected from all parts of the world, namely; the UK, 
the United States, Ireland, Australia, New Zealand, the Caribbean, Canada, India, Singapore, and South Africa (The Oxford Dictionaries, 2018).

Arabic corpora started to appear in the late 1980s. They differ in size, type, purpose of development, and the materials used to develop them (Al-Sulaiti \& Atwell 2006). Freely available Arabic corpora were surveyed by Zaghouani (2014). The survey categorized 66 freely available Arabic corpora into; (i) Raw Text Corpora such as monolingual corpora, multilingual corpora, dialectal corpora, and web-based corpora. (ii) Annotated Corpora such as named entities, error annotation, part-of-speech, syntax, semantic, and anaphora. (iii) Lexicons such as lexical databases and words lists. (iv) Speech Corpora such as audio recordings and transcribed data. (v) Handwriting Recognition Corpora such as scanned and annotated documents. (vi) Miscellaneous Corpora such as questions/answers, comparable corpora, plagiarism detection and summaries.

The first freely available Arabic corpus was the Corpus of Contemporary Arabic (Al-Sulaiti \& Atwell 2006). It contains 1 million words collected from newspapers and magazines text. Most monolingual raw text of Arabic corpora cover the news domain. Examples of such corpora are; OSAC: Open Source Arabic Corpora (Saad \& Ashour 2010); Khaleej-2004 corpus (Abbas \& Smaili 2005); Watan-2004 corpus (Abbas et al, 2011); KACST Arabic Newspaper Corpus (Al-Thubaity et al. 2013); Arabic Words Corpus which is a frequency list of 1.5 million words collected by Al-Saadi. The International Corpus of Arabic (ICA) project by Bibliotheca Alexandrina (BA) was planned to construct a corpus that contains 100 million from Press, Net articles, books and academic text sources. The ICA was planned to cover the Arabic language as being used all over the Arab world (Alansary \& Nagi, 2014). Alrabiah el al, (2013) developed the King Saud University Corpus of Classical Arabic (KSUCCA) which consists of around 50 million words. It was collected from authenticated Classical Arabic texts. It was constructed to study the language of the Qur'an using distributional lexical semantics.

Ismail, et al, (2014) developed a set of computational tools and corpus resources that would facilitate research in historical semantics and etymological lexicography. They constructed Historical Arabic Corpus (HAC) with around 45 million tokens in the first phase of development. They analyzed the collected text automatically and they annotated the text with linguistic information such as; part-of-speech, root, and morphological pattern. This corpus was collected from about 500 sources that represent 1600 years of continuous language use which represent the entire recorded history of the Arabic language. Additionally, they developed a corpus builder that integrates a stemmer with a tagger to process and annotate documents, and then compile them into an XML-formatted corpus. They also created an indexer, a search engine, a concordancer and a dictionary editor that together facilitate searching and extraction of linguistic knowledge from HAC. Also, these tools facilitate the compilation of dictionary entries in a hypothetical dictionary on historical principles.

Since the release of COBUILD, corpora proved to be excellent resources for developing new dictionaries. In addition to lexical information, corpora can provide more useful information that would enrich dictionaries such as idioms, phrases, collocates, word sketches and thesauri of words. Arabic corpora were not yet used to construct most existing Arabic dictionaries (Al-Sulaiti \& Atwell, 2006). Ghazali \& Barham (2001) criticized existing Arabic dictionaries for literal translations of their lexical items and the lack of idioms; phrasal verbs; collocations; and new words entering the language. Based on a corpus of 1.5 million words, they investigated the different meaning of the verb أَخَ 'a hada 'he took' on both the corpus and Al-Waseet Arabic dictionary. In addition to its literal meaning, they discovered two additional meanings using the corpus which were not mentioned in Al-Waseet Arabic dictionary.

Recently, corpora are used to build bilingual dictionaries for Modern Standard Arabic (van Mol, 2000; van Mol \& Paulussen, 2001; Hoogland, 1996; Zemank, 2001). A corpus of 3 million words was constructed to develop a Dutch-Arabic/Arabic-Dutch dictionary (van Mol, 2000). Older version of the Dutch-Arabic/Arabic-Dutch dictionaries were constructed using a 2 milion-word corpus (Hoogland, 1996). Likewise, a corpus of 50 million words was used to develop an Arabic-Czech dictionary (Zemank, 2001).

Moreover, The Oxford Arabic Corpus (OAC) consists of 880 million words. It is used to construct the Oxford Arabic Dictionary (OAD) (Arts \& McNeil 2013, Arts 2014). They used the Oxford Arabic Corpus with Sketch Engine to eliminate unnatural examples, to add appropriate examples showing natural usage, to identify modern senses of old words, and to include new vocabulary in the constructed dictionary.

Furthermore, a jellyfish dictionary for Arabic was developed using a large-scale Arabic corpus. A jellyfish dictionary is defined as a self-updating and automatically monitoring language change. Three motivations for developing a jellyfish dictionary for Arabic are (i) discovering new words; (ii) flagging obsolete words; and (iii) recognizing new senses. The large-scale Arabic corpus used to develop the jellyfish dictionary is consisted of 1 billion words (Attia \& van Genabith, 2013). 
type (i.e. part of speech) and the meaning of that word. On the other hands, Arabic lexicons depend on roots as lexical entries.

The first arrangement methodology of lexical entries of Arabic lexicons is the al-halīl methodology. It was developed by الخليل بن أحمد الفراهيدي al-h́līl bin ahmad al-farāhīdī (died in 791). The second arrangement methodology is the al-ğawhar methodology which was developed by 'ismā' $\bar{l}$ bin hammād al-ğawharī (died in 1002). The al-barmaki methodology is the third arrangement methodology. This arranging method was developed by abū al-ma álì mohammad bin tamīm al-barmakī أبو المعالي محمد بن تميم البرمكي, who lived in the same time period as al-ğawharī. al-barmakī did not construct a new lexicon; but he alphabetically re-arranged a lexicon called aṣ-șihāh fi al-luḡah الصحاح في اللغة 'The Correct Language' by al-ğawharī. For these three ordering methods, roots are considered the lexical entries. The last methodology is the $a b \bar{u}$ ' $u b a y d$ methodology which was developed by abū 'ubayd al-qāsim bin sallām أبو عُبيدٍ القاسم بن سلآم (died in 838). The following sections discuss the arrangement methodologies for lexical entries of traditional Arabic dictionaries.

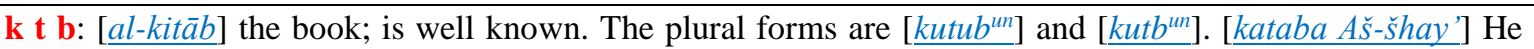
wrote something. [yaktubuhu] the action of writing something. [katb $\left.{ }^{a n}\right],\left[k i t a \bar{b} b^{a n}\right]$ and $\left[k i t a \bar{b} b a t^{a n}\right]$ means the art of writing. And [ kattabahu] writing it means draw it up. Abu Al-Najim said: I returned back from Ziyad's house [after meeting him] and behaved demented, my legs drawn up differently (means walking in a different way). They wrote [tukattibāni] on the road the letters of Lam Alif (describing how he was walking crazily and in a different way). He said: I saw in a different version, the word "they wrote" [tikittibanni] using the short vowel kasrah on the first letter [tā'], as it is used by Bahrā' [Arab tribe] dialect. They say: (ti'lamuwn) (you know). Then the short vowel kasrah is propagated to the following letter (kāf). Moreover, [al-kitāb] the book is a noun. Al-lihyānn̄ Al-'zharī definition is: [al-kitāb] The book is the name of a collection of what has been written (a collection of written materials or texts). And the book has gerund [al-kitābatu] writing (art of writing) for whoever has a profession, similar to drafting and sewing. And [al-kitābatu]: is copying a book (copying a book in several copies). It is said: [iktataba] someone subscribed another means; he asked to write him a letter in something. [istaktabahu] He dictated someone something means to write him something. Ibn Sayyedah: [iktatabahu] is similar to [katabahu]. It is said: [katabahu] write something down means draw up. And [iktatabahu] writing something down means dictate someone something, which is the same meaning of [istaktabahu]. [iktatabahu] registering (masculine), and [iktatabathu] registering (feminine). In the Qur'an: [iktatabaha] He registered it, he has dictated it every sunrise and sunset, which means dictating it. It is said: [iktataba ar-rajul] The man registered, if he registered himself in the Sultan's office. In Hadith: a man said to him (the prophet): my wife is pilgrimaging (to Mecca), and I have registered [uktutibtu] in a conquest, which means that I have written my name among the conquerors. And you say: ['aktibnī] let me copy this poem, means dictate me the poem. Also, $[\underline{a l-k i t a \bar{b}]}$ the book is something which has been written on. And in Hadith: who looks at his brother's book without permission is as looking to hell. Ibn Al-Atheer said: it is a similarity; which means as he avoids hell, he should avoid doing this. He said: the meaning (of the Hadith) is the punishment by hell will be applied if someone looks at a book without permission. He said: it might be the punishment of visual explorers as the crime is done by sight. Hearing explorer is punished if someone intentionally listened to other people who do not like anyone to listen to them. He said: this Hadith is specific for books of secrets and secure books, whose owners hate anybody to look at these books. It is also said: the Hadith is general; applied to any type of books [kitāb].

Figure 2. A human translation of the sample of text from the traditional Arabic lexicon "lisān al- "arab", the target lexical entries are highlighted in blue and square brackets

\subsection{The al-halīl Ordering Methodology}

The first traditional Arabic lexicon is called كتاب العبين الغليل al-halīl bin aḥmad al-farāhīdī (died in 791). The al-halīl ordering methodology, which was followed in constructing 'The al-'ayn' lexicon, arranges the lexical entries phonologically according to places of articulation of phonemes from the mouth and throat, working forwards from glottal through to labial regions. The al- 'ayn lexicon was divided into books, where one book was dedicated for each letter. Each book was then divided into 4 sections according to their internal structure: (i) doubled biliteral roots; (ii) intact triliteral roots; (iii) doublydefective roots; and (iv) quadriliteral and quinquitiliteral roots. Many lexicons followed al-halīl's methodology with slight modifications. Table [1] lists some of traditional Arabic Lexicons that followed al-halīl's methodology. 


\subsection{The al-ğawharī Methodology}

الصحاح في اللغة constructed a lexicon called اسماعيل بن حمًاد الجوهري (died in 1002) ass-șihāh fi al-lug $a^{h}$ 'The Correct Language'. Roots are the lexical entries of this lexicon. They were alphabetically ordered according to their last letter, then the first letter. This methodology is called the al-ğawhari methodology. The lexicon was organized into chapters where each chapter corresponds to the last letter of the root. Each chapter includes sections corresponding to the first letter of the root, then the second letter of triliteral roots, then the third letter of quadriliteral roots, then the fourth letter in quinquitiliteral roots. For example, the word بَ bașat "spread" which is derived from the root (b-s-t) is found in chapter $b t$ representing the last letter of the root, and in section ب representing the first letter of the root. Table [1] lists some of traditional Arabic Lexicons that followed this ordering methodology.

\subsection{The al-barmaki Methodology}

The third lexicon ordering methodology is "The al-barmakī methodology". It was developed by abū al-ma 'âli muhammad bin tamìm al-barmaki أبو المعالي محمد بن تميم البرمكي (died in 1006). In this methodology, lexical entries (i.e. roots) are alphabetically arranged according to the first letter of the root. al-barmaki lived in the same period as al-ğawharī. al-barmakī did not construct a new Arabic lexicon. Instead, he re-arranged the lexical entries

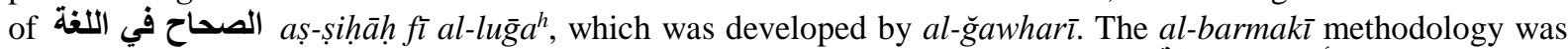

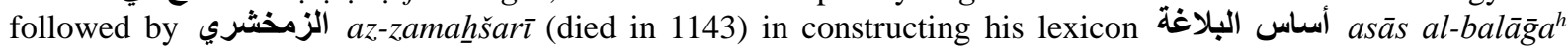
"Fundamentals of Rhetoric". Table [1] lists Arabic lexicon which followed the al-barmaki methodology for ordering lexical entries. The al-barmaki methodology for ordering lexical entries becomes the most widely used ordering methodology for Arabic lexicons.

\subsection{The abu' 'ubayd Methodology}

abù 'ubayd al-qāsim bin sallām أبو عُبيد القاسم بن سلاًّم (died in 838) developed the fourth ordering methodology for Arabic lexicons which is called "The abu 'ubayd methodology". This methodology arranges and groups together lexical entries according to their semantic fields. This arrangement methodology is similar to arranging lexical entries in modern thesauri. Many lexicons followed this ordering methodology. الغزريب المُصنّف في اللغة al-


lexicon that followed this methodology. This lexicon includes many small books that describe similar topics (i.e. group words of similar meanings) such as books describing horses, milk, honey, flies, insects, palms, and human creation. Then, more than thirty small books were collated into one large lexicon. Figure [3] shows a sample from Colours' Book taken from al-ğarīb al-mușannaf fì al-luğg $a^{h}$ lexicon. Table [1] lists traditional Arabic lexicons that followed $a b \bar{\imath}$ ' ubayd methodology.

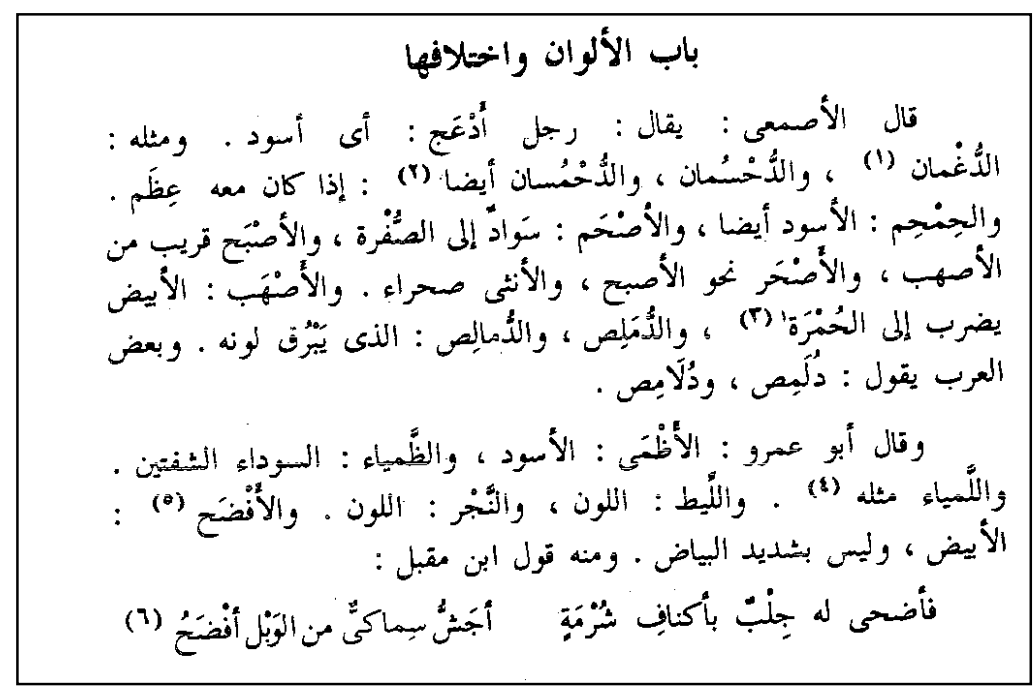

Figure 3. A sample of الغريب المُصنّف في اللغة al-ğarīb al-mușannaf fí al-luḡga "The Irregular Classified Language" lexicon 
Table 1. Examples of Traditional Arabic Lexicons classified according to their Arrangement Methodology

\begin{tabular}{|c|c|}
\hline $\begin{array}{l}\text { Arrangement } \\
\text { Methodology }\end{array}$ & Traditional Arabic Lexicons following this Arrangement Methodology \\
\hline \multirow[t]{5}{*}{$\begin{array}{l}\text { 1. The al-halīl } \\
\text { Methodology }\end{array}$} & $\begin{array}{l}\text { 1- كتاب العين kitābu al- 'ayn “al-'ayn Lexicon” by الخليل ابن أحمد الفراهيدي al-halīl bin ahmad } \\
\text { al-farāhìdì (died in 175H / 791AD). }\end{array}$ \\
\hline & 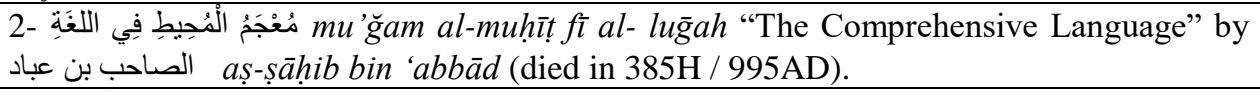 \\
\hline & 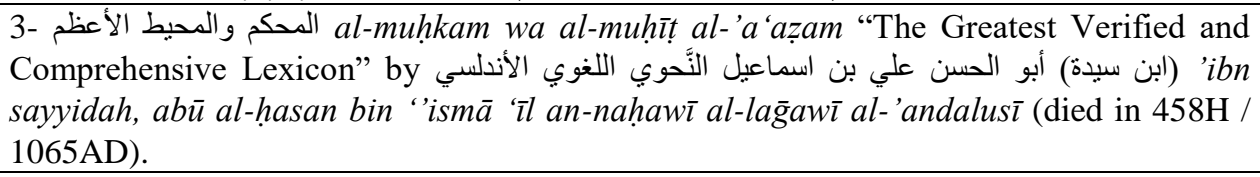 \\
\hline & 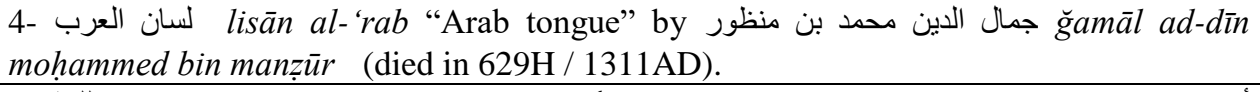 \\
\hline & 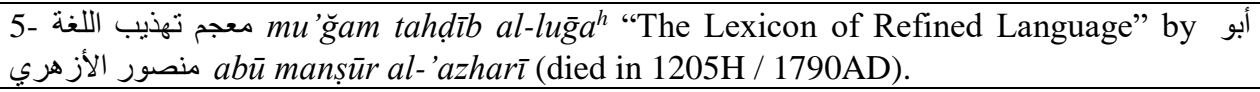 \\
\hline \multirow[t]{4}{*}{$\begin{array}{l}\text { 2. The al-ğawharī } \\
\text { Methodology }\end{array}$} &  \\
\hline & 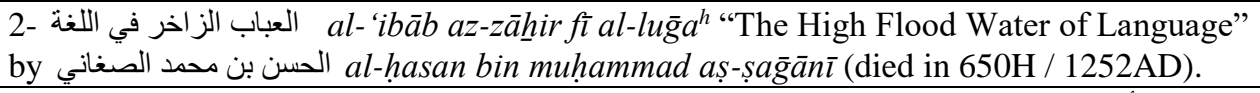 \\
\hline & 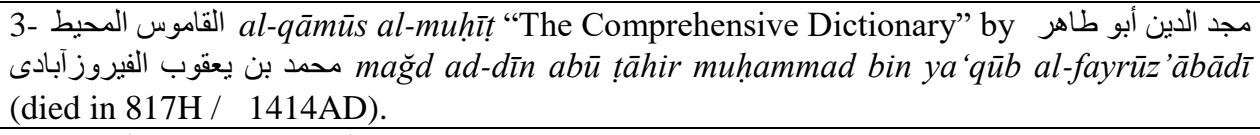 \\
\hline & 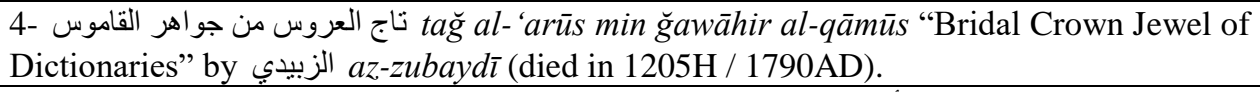 \\
\hline \multirow[t]{11}{*}{$\begin{array}{l}\text { 3- The al-barmaki } \\
\text { methodology }\end{array}$} & 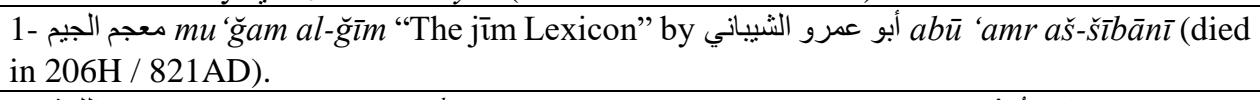 \\
\hline & 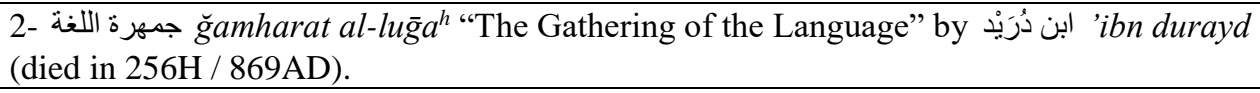 \\
\hline & 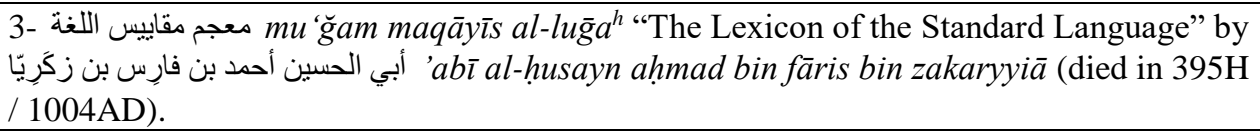 \\
\hline & 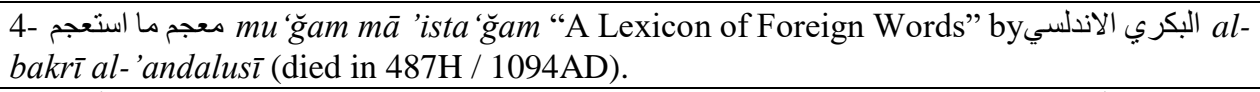 \\
\hline & 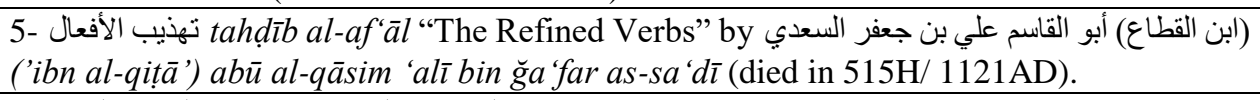 \\
\hline & 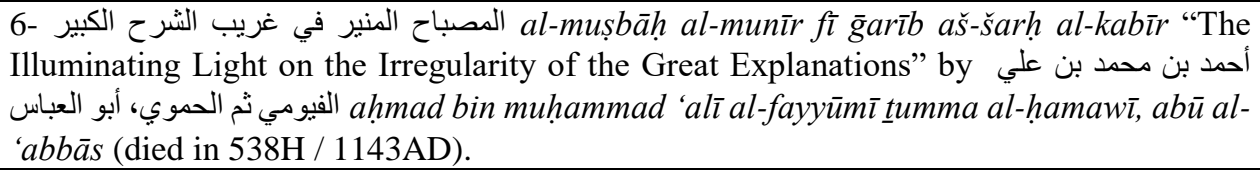 \\
\hline & 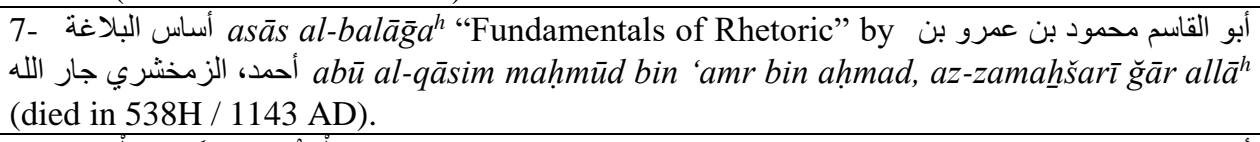 \\
\hline & 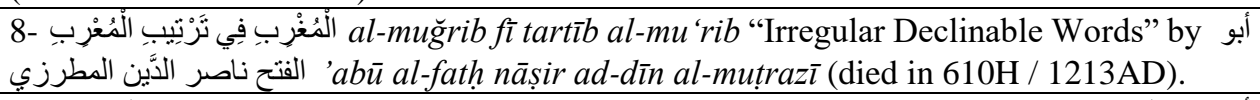 \\
\hline & 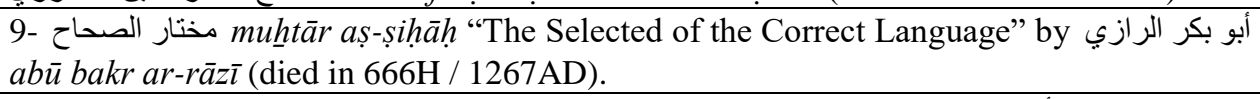 \\
\hline & 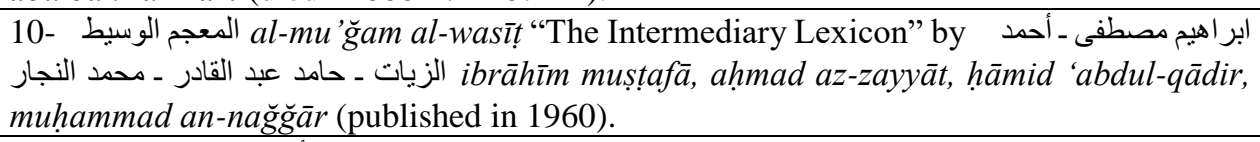 \\
\hline & 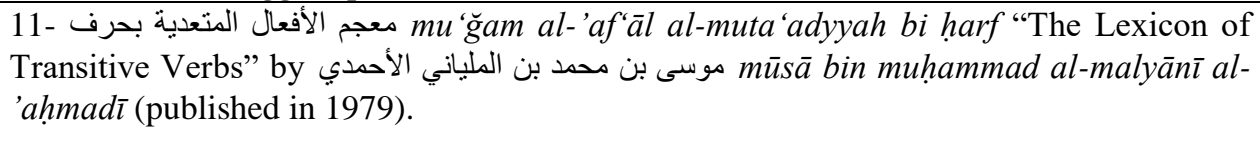 \\
\hline
\end{tabular}


formats from MS Word or HTML web pages into standard text files in Unicode 'utf-8' encoding. (ii) A statistical analysis was applied that computed the words frequencies and the vocabulary size for both vowelized and nonvowelized text of the corpus. As a result, the complete TAL-Corpus contains 14369570 words, 2184315 vowelized word types and 569412 non-vowelized word types (i.e. after removing short vowels (diacritics) from the text). Table [2] shows the summary of the statistical analyses of the lexicon texts used to construct the TALCorpus. Figure [5] shows the highest 25 frequent words in the TAL-Corpus of partially vowelized and nonvowelized forms of words.

Table 2. Statistical Analysis of the Lexicons' Text used to construct the TAL-Corpus

\begin{tabular}{l|l|l}
\hline Number of files & & $\mathbf{2 4 7}$ \\
\hline Size & Number of words & $\mathbf{1 7 8 . 3 2} \mathbf{M B}$ \\
\hline Vowelized word & Number of word types & 214369570 \\
\cline { 2 - 3 } & Number of words & 14369570 \\
\hline Non-vowelized word & Number of word types & 569412 \\
\hline
\end{tabular}

\begin{tabular}{|c|c|c|c|c|c|}
\hline \multicolumn{3}{|c|}{ Partially-vowelized } & \multicolumn{3}{|c|}{ Non-vowelized } \\
\hline \multicolumn{2}{|c|}{ Word } & \multirow{2}{*}{$\begin{array}{r}\text { Frequency } \\
292396\end{array}$} & \multicolumn{2}{|c|}{ Word } & \multirow{2}{*}{$\begin{array}{r}\text { Frequency } \\
322239\end{array}$} \\
\hline في & $f i$ "in" & & من & $\min$ "from" & \\
\hline من & min "from" & 269200 & في & $f_{l}$ "in" & 301895 \\
\hline 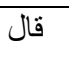 & $q \bar{a} l$ "he said" & 172631 & قال & $q \bar{a} l$ "he said" & 190918 \\
\hline g & $w a$ "and" & 120060 & أي & 'ayy "which" & 132635 \\
\hline على & 'alā "over" & 108252 & 9 & $w a$ "and" & 130809 \\
\hline ما & $m \bar{a}$ "what" & 89195 & على & 'alā "over" & 119639 \\
\hline وقال & wa qāl "and he said" & 88233 & إذا & 'ihhā “if” & 115842 \\
\hline عن & 'an "about" & 82027 & وقال & wa qāl "and he said" & 99601 \\
\hline إذا & 'ihhā "if" & 81479 & ابن & 'ibn "son of" & 94980 \\
\hline 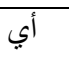 & 'ay "which" & 78622 & ما & $m \bar{a}$ "what" & 94530 \\
\hline وهو & wa huwa "and he" & 75149 & بن & bin "son of" & 92213 \\
\hline$y$ & lā" "no" & 69737 & عن & "an "about" & 87064 \\
\hline ابن & 'ibn "son of" & 58334 & وهو & wa huwa "and he" & 80375 \\
\hline به & bihi "in it" & 53343 & $y$ & lā "no" & 73066 \\
\hline وفي & wa fi "and in" & 53197 & أبو & $a b \bar{u}$ "father" & 72231 \\
\hline وقد & wa qad "and perhaps" & 50648 & 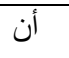 & 'an "that" & 65419 \\
\hline أبو & $a b \bar{u}$ "father" & 47915 & أو & 'aw "or" & 62298 \\
\hline بن & bin "son of" & 46880 & الله & allā "Allah" & 59511 \\
\hline أُبي & 'ay "which" & 46788 & به & bihi "in it" & 58941 \\
\hline هو & huwa "he" & 45916 & يقال & $y u q \bar{a} l$ "it is said" & 58062 \\
\hline يقال & $y u q \bar{a} l$ "it is said" & 45794 & وفي & wa fil "and in" & 55077 \\
\hline عليه & 'alayhi "about him" & 44786 & وقد & wa qad "and perhaps" & 53992 \\
\hline g & wa lā "and not" & 42190 & عليه & 'alayhi "about him" & 50906 \\
\hline الله & alla $^{h}$ "Allah" & 39961 & هو & huwa "he" & 49785 \\
\hline
\end{tabular}

Figure 5. The first 25 words of the frequency list generated from the TAL-Corpus Corpus 
The analysis represented by Tables [3] and [4] and Figure [6] classifies the traditional Arabic lexicons which were include in the TAL-Coprus, according to the time of construction. The time period spans around 14 centuries since the first Arabic lexicon was created (i.e. from the second Hijri century to the fifteenth Hijri century). This time span was divided into 14 time frames where each corresponds to 100 years. These time frames were defined by the creation times of the traditional Arabic dictionaries which are indicated by the death date of dictionaries' authors. The first time frame includes one lexicon kitäbu al- 'ayn which consists of 348114 words and 141098 word types which forms $2.42 \%$ of the text size and $3.72 \%$ of the vocabulary size of the TAL-Corpus. The lexicons from $12^{\text {th }}$ century are the largest. They contain 5215917 words and 1211432 word types. They form $36.30 \%$ of the TAL-Corpus text and $31.90 \%$ of its vocabulary size. The lexicons included in this time frame are tağ al- 'arūs

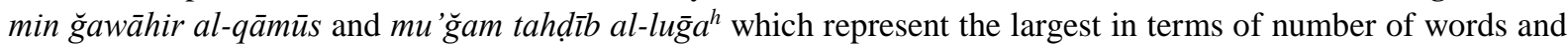
vocabulary size.

Table 3. Text and vocabulary size of the Traditional Arabic Dictionaries and their percentage in the TAL-Corpus

\begin{tabular}{|c|c|c|c|c|c|c|c|}
\hline & Time Frame & Lexicon Name & $\begin{array}{l}\text { Date } \\
\text { (Died in) }\end{array}$ & \# Words & \# Types & $\begin{array}{l}\text { \% of } \\
\text { Words }\end{array}$ & $\begin{array}{l}\text { \% of } \\
\text { Types }\end{array}$ \\
\hline 1 & $\begin{array}{l}\text { 100-199H, } \\
\text { 718-814AD }\end{array}$ & kitābu al- 'ayn كتاب العين & $\begin{array}{l}175 \mathrm{H} \\
(791 \mathrm{AD})\end{array}$ & 348,114 & 141,098 & $2.42 \%$ & $3.72 \%$ \\
\hline 2 & $\begin{array}{l}\text { 200-299H, } \\
\text { 815-911AD }\end{array}$ & 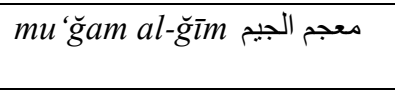 & $\begin{array}{l}206 \mathrm{H} \\
(821 \mathrm{AD})\end{array}$ & 125,676 & 56,274 & $0.87 \%$ & $1.48 \%$ \\
\hline \multirow[t]{2}{*}{3} & $\begin{array}{l}\text { 300-399H, } \\
\text { 912-1008AD }\end{array}$ & 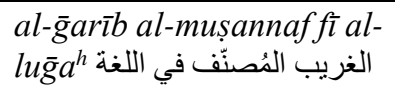 & $\begin{array}{l}223 \mathrm{H} \\
(838 \mathrm{AD})\end{array}$ & 16,541 & 7,775 & $0.12 \%$ & $0.20 \%$ \\
\hline & & جمهرة اللغة & $\begin{array}{l}256 \mathrm{H} \\
(869 \mathrm{AD})\end{array}$ & 396,144 & 123,576 & $2.76 \%$ & $3.25 \%$ \\
\hline & &  & $\begin{array}{l}310 \mathrm{H} \\
(922 \mathrm{AD})\end{array}$ & 32,173 & 16,942 & $0.22 \%$ & $0.45 \%$ \\
\hline & & 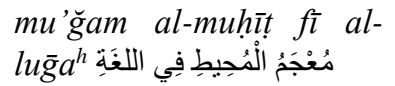 & $\begin{array}{l}385 \mathrm{H} \\
(995 \mathrm{AD})\end{array}$ & 392,246 & 168,870 & $2.73 \%$ & $4.45 \%$ \\
\hline & & 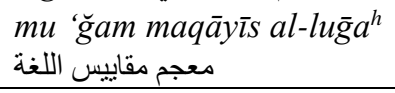 & $\begin{array}{l}395 \mathrm{H} \\
(1004 \mathrm{AD})\end{array}$ & 445,126 & 129,838 & $3.10 \%$ & $3.42 \%$ \\
\hline \multirow[t]{4}{*}{4} & $\begin{array}{l}\text { 400-499H, } \\
1009-1105 \mathrm{AD}\end{array}$ & $\begin{array}{l}\text { aṣ-sihāạh fí al-luḡ } a^{h} \\
\text { الصحاح في اللغة }\end{array}$ & $\begin{array}{l}400 \mathrm{H} \\
(1009 \mathrm{AD})\end{array}$ & 593,654 & 118,591 & $4.13 \%$ & $3.12 \%$ \\
\hline & & $\begin{array}{l}\text { al-muhkam wa al-muhịt } \\
\text { al-'a'azam } \\
\text { المحكم والمحيط الأعضم }\end{array}$ & $\begin{array}{l}458 \mathrm{H} \\
(1065 \mathrm{AD})\end{array}$ & $1,020,137$ & 279,157 & $7.10 \%$ & $7.35 \%$ \\
\hline & & 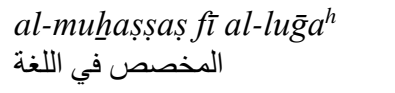 & $\begin{array}{l}458 \mathrm{H} \\
(1065 \mathrm{AD})\end{array}$ & 902,324 & 274,780 & $6.28 \%$ & $7.24 \%$ \\
\hline & & 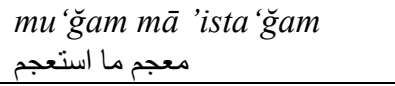 & $\begin{array}{l}487 \mathrm{H} \\
(1094 \mathrm{AD})\end{array}$ & 278,713 & 43,289 & $1.94 \%$ & $1.14 \%$ \\
\hline 5 & $\begin{array}{l}500-599 \mathrm{H}, \\
1106-1202 \mathrm{AD}\end{array}$ & tahdì̄b al-af'äl تهذيب الأفعال & $\begin{array}{l}515 \mathrm{H} \\
(1121 \mathrm{AD}) \\
\end{array}$ & 132,319 & 38,102 & $0.92 \%$ & $1.00 \%$ \\
\hline \multirow[t]{4}{*}{6} & $\begin{array}{l}600-699 \mathrm{H}, \\
1203-1299 \mathrm{AD}\end{array}$ & $\begin{array}{ll}\text { أساس } & \text { أسلاس }\end{array}$ & $\begin{array}{l}538 \mathrm{H} \\
(1143 \mathrm{AD})\end{array}$ & 289,436 & 95,887 & $2.01 \%$ & $2.52 \%$ \\
\hline & & 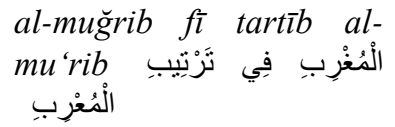 & $\begin{array}{l}610 \mathrm{H} \\
(1213 \mathrm{AD})\end{array}$ & 128,047 & 39,930 & $0.89 \%$ & $1.05 \%$ \\
\hline & & 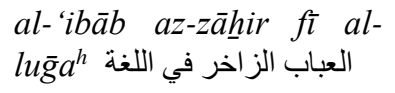 & $\begin{array}{l}650 \mathrm{H} \\
(1252 \mathrm{AD})\end{array}$ & 261,658 & 100,536 & $1.82 \%$ & $2.65 \%$ \\
\hline & & 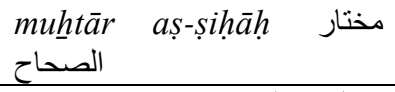 & $\begin{array}{l}666 \mathrm{H} \\
(1267 \mathrm{AD})\end{array}$ & 171,487 & 40,295 & $1.19 \%$ & $1.06 \%$ \\
\hline \multirow[t]{2}{*}{7} & $\begin{array}{l}700-799 \mathrm{H}, \\
1300-1396 \mathrm{AD}\end{array}$ & لسان العرب ل lisān al-'rab & $\begin{array}{l}711 \mathrm{H} \\
(1311 \mathrm{AD})\end{array}$ & $2,146,545$ & 507,860 & $14.94 \%$ & $13.37 \%$ \\
\hline & & 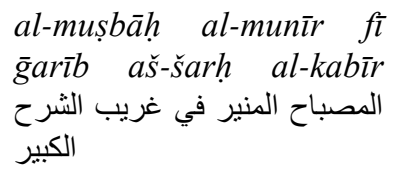 & $\begin{array}{l}770 \mathrm{H} \\
(1368 \mathrm{AD})\end{array}$ & 219,276 & 61,422 & $1.53 \%$ & $1.62 \%$ \\
\hline 8 & $800-899 \mathrm{H}$, & al-qāmūs al-muḥitt & $817 \mathrm{H}$ & 563,460 & 203,600 & $3.92 \%$ & $5.36 \%$ \\
\hline
\end{tabular}




\begin{tabular}{|c|c|c|c|c|c|c|c|}
\hline & 1397-1493AD & القاموس المحيط & (1414AD) & & & & \\
\hline \multirow[t]{2}{*}{12} & $\begin{array}{l}\text { 1200-1299H, } \\
1785-1881 \mathrm{AD}\end{array}$ & 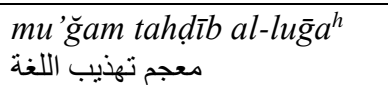 & $\begin{array}{l}1205 \mathrm{H} \\
(1790 \mathrm{AD})\end{array}$ & $1,351,837$ & 379,928 & $9.41 \%$ & $10.00 \%$ \\
\hline & & $\begin{array}{l}\text { tağ al-'arūs min ğawāhir } \\
\text { al-qūmūs } \\
\text { تاج العروس من جواهر القاموس }\end{array}$ & $\begin{array}{l}1205 \mathrm{H} \\
(1790 \mathrm{AD})\end{array}$ & $3,864,080$ & 831,504 & $26.89 \%$ & $21.89 \%$ \\
\hline 13 & $\begin{array}{l}\text { 1300-1399H, } \\
1882-1978 \mathrm{AD}\end{array}$ & $\begin{array}{l}\text { al-mu'ğam al-wasīt } \\
\text { المعجم الوسيط }\end{array}$ & $\begin{array}{l}\text { Modern } \\
1960\end{array}$ & 615,352 & 112,164 & $4.28 \%$ & $2.95 \%$ \\
\hline 14 & $\begin{array}{l}\text { 1400H-Today, } \\
\text { 1979AD }\end{array}$ & $\begin{array}{l}\text { mu'ğam al-'af'āl al- } \\
\text { muta'dyyah bi harf } \\
\text { معجم الأفعال المتعدية بحرف }\end{array}$ & $\begin{array}{l}\text { Modern } \\
1979\end{array}$ & 75,225 & 26,299 & $0.52 \%$ & $0.69 \%$ \\
\hline
\end{tabular}

Table 4. The 14 Time frames and their percentage of words and vocabulary size in the TAL-Corpus.

\begin{tabular}{lllllll}
\hline Frame & Time frame & \# of dictionaries & \# words & \# types & \% of words & \% of types \\
\hline 1 & $100 \mathrm{H}-199 \mathrm{H}(718 \mathrm{AD}-814 \mathrm{AD})$ & 1 & 348,114 & 141,098 & $2.42 \%$ & $3.72 \%$ \\
2 & 200H-299H (815AD-911AD) & 3 & 538,361 & 187,625 & $3.75 \%$ & $4.94 \%$ \\
3 & 300H-399H (912AD-1008AD) & 3 & 869,545 & 315,650 & $6.05 \%$ & $8.31 \%$ \\
4 & $400 \mathrm{H}-499 \mathrm{H}(1009 \mathrm{AD}-1105 \mathrm{AD})$ & 4 & $2,794,828$ & 715,817 & $19.45 \%$ & $18.85 \%$ \\
5 & $500 \mathrm{H}-599 \mathrm{H}(1106 \mathrm{AD}-1202 \mathrm{AD})$ & 1 & 132,319 & 38,102 & $0.92 \%$ & $1.00 \%$ \\
6 & 600H-699H (1203AD-1299AD) & 4 & 850,628 & 276,648 & $5.92 \%$ & $7.28 \%$ \\
7 & 700H-799H (1300AD-1396AD) & 2 & $2,365,821$ & 569,282 & $16.46 \%$ & $14.99 \%$ \\
8 & 800H-899H (1397AD-1493AD) & 1 & 563,460 & 203,600 & $3.92 \%$ & $5.36 \%$ \\
9 & $900 \mathrm{H}-999 \mathrm{H}(1494 \mathrm{AD}-1590 \mathrm{AD})$ & 0 & - & - & - & - \\
10 & $1000 \mathrm{H}-1099 \mathrm{H}(1591 \mathrm{AD}-1687 \mathrm{AD})$ & 0 & - & - & - & - \\
11 & $1100 \mathrm{H}-1199 \mathrm{H}, 1688 \mathrm{AD}-1784 \mathrm{AD}$ & 0 & - & - & - & - \\
12 & $1200 \mathrm{H}-1299 \mathrm{H}, 1785 \mathrm{AD}-1881 \mathrm{AD}$ & 2 & $5,215,917$ & $1,211,432$ & $36.30 \%$ & $31.90 \%$ \\
13 & $1300 \mathrm{H}-1399 \mathrm{H}, 1882 \mathrm{AD}-1978 \mathrm{AD}$ & 1 & 615,352 & 112,164 & $4.28 \%$ & $2.95 \%$ \\
14 & $1400 \mathrm{H}-$-Today, 1979AD & 1 & 75,225 & 26,299 & $0.52 \%$ & $0.69 \%$ \\
\hline
\end{tabular}

\section{Traditional Arabic Dictionaries}

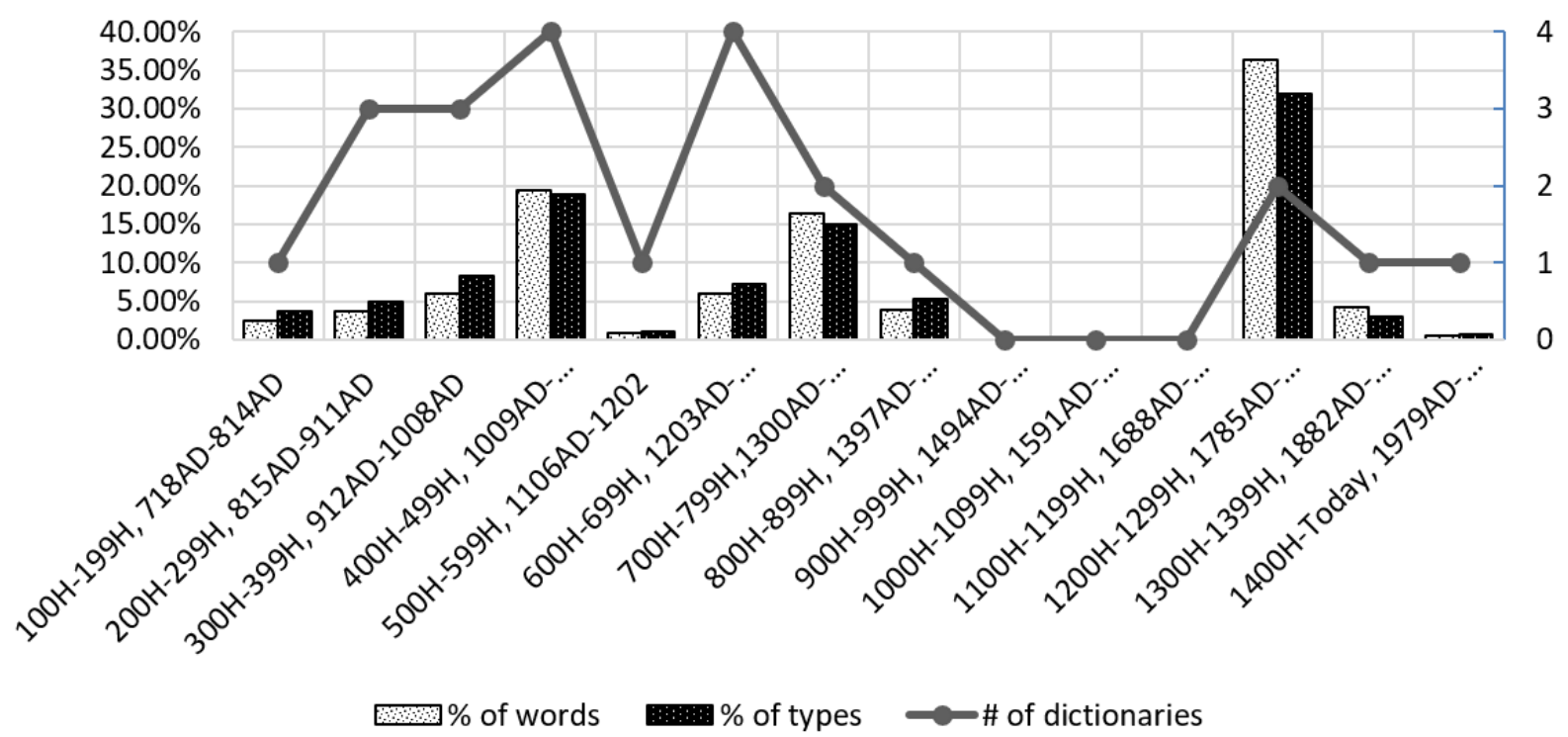

Figure 6. Traditional Arabic dictionaries included in the TAL-Corpus 
After collecting the text of 23 traditional Arabic dictionaries, common pre-processing steps were applied. First, all dictionaries' files were converted into standard text files using Unicode 'utf- 8 ' encoding. Then, the SALMATokenizer and the SALMA-root extractor and Lemmatizer (Sawalha, 2011) were used to tokenize and process Arabic words by striping diacritics, and extracting the root and the lemma for each word in the TAL-Corpus. Third, frequency lists of both vowelized and non-vowelized word were generated (see Table [1] and Figure [5]).

Special algorithm was developed to extract the derived words of the lexical entries for the dictionaries included in the TAL-Corpus. The purpose of this algorithm is to group together roots and their definition parts and then to extract derived words of roots from their related definition articles. To achieve this goal, a specific treatment were applied to each dictionary text. The 23 collected dictionaries were originally constructed following an ordering methodology of their lexical entries as discussed in Section 2. Most of them use roots as their main head words of lexical entries. These dictionaries were typed into machine-readable files in different formats without using any lexicographic representations that can be recognized by Computers. Therefore, specialized programs were developed for each dictionary to reformat and extract useful information such as roots, definitions and derived words.

The root-definition structure is the common basic structure for most traditional Arabic dictionaries. Each lexical entry consists of the root as a head word and the definition part. The definition part is written as an encyclopaedic article featuring free writing style. These encyclopaedic articles defines the root and its derived words and their linguistic attributes are specified. However, the derived words of a root within the definition part are neither structured nor ordered. This free writing style requires the authors of dictionaries to add affixes and clitics to the derived words within the definition parts. Clitics, such as conjunctions, prepositions and connected pronouns, are used to connect sentences and paragraphs of these definition articles.

For the above mentioned-reasons, the free writing style of the definition part adds extra challenges to extract the derived words and their definitions. Therefore, a dedicated algorithm was developed to extract the roots and their derived words from the dictionaries' texts. The tokenizing module in the program specifies the boundaries of a lexical entry which is normally starts with a root followed by an article that defines that root. For each lexical entry, the algorithm extracts and pairs words from the definition part with the root and stores them in vectors (i.e. bag of words). Many of these word-root pairs are not correct matches (i.e. the word is not derived from the associated root). A normalization analysis verified these word-root pairs by throwing out pairs where the word is not derived from its associated root. The normalization procedure applies linguistic knowledge that governs the derivation process of words from their roots. These linguistic rules were used to match the consonant letters of words and roots and their order for each word-root pair. The first linguistic rule checks if all consonant letters forming the root appear in the paired word. The second rule examines if all root letters orderly appear in the derived word. Both rules must be applied to every word-root pair for verification. This process is applied to extract the derived words of a root and later to build a morphological lexicon (See Section 3.3.1). Figure [7] shows the process of selecting word-root pairs. Table [5] shows the number of words and the percentage of words extracted from the original text of the dictionaries.

\begin{tabular}{|c|c|c|c|c|}
\hline \multicolumn{5}{|c|}{ Word-root vector for the root كتب k-t-b } \\
\hline (مُخْتَلِفْ ، كتبب) & (عنْدِ ، كتب) & (خَطُه ، كتبَ) & (كتب، الثيءً) & (الكِتابُ ، كتب!) \\
\hline (تُكَتِّان ، كتب ) & (زيادٍ ، كتب) & (قال ، كتب) & (كتب، يَكْتُبهَ) & (معروف ، كتب) \\
\hline (في ، كتب) & (كالخَرِفْ ، كتب) & (أَبو ، كتب) & (كتب، كَتْباً) & (و الجمع ، كتب) \\
\hline (الطّريتي ، كتب) & (تَخُطٌ ، كتب) & (النجم ، كتب) & (وكِتاباً ، كتب) & (كُتُبْ ، كتب) \\
\hline (لامَ ، كتب) & (رِجْلايَ ، كتب) & (أَفْبَتْتُ ، كتب) & (وكِتابةً ، كتب) & (كُتْبُ ، كتبَ) \\
\hline (أَلِفْت ، كتب) & (بخَةٍ ، كتب) & (من ، كتب) & (وكَتَّبه ، كتب) & (كَتَبَ ، كتبَ) \\
\hline
\end{tabular}

Figure 7. Using linguistic knowledge to select word-root pairs from traditional Arabic lexicons. The selected word-root pairs are underlined and highlighted in blue

Table 5. Words and Roots Extracted from 8 Traditional Arabic lexicons

\begin{tabular}{llll}
\hline Lexicon name & $\begin{array}{l}\text { Word } \\
\text { types }\end{array}$ & Words extracted & $\begin{array}{l}\text { Roots } \\
\text { extracted }\end{array}$ \\
\hline
\end{tabular}




\begin{tabular}{|c|c|c|c|c|c|}
\hline 1 & tağ al- 'arūs min ğawāhir al-qāmūs & 831,504 & 474,351 & $57.05 \%$ & 11,101 \\
\hline 2 & lisān al- 'rab & 507,860 & 274,305 & $54.01 \%$ & 9,355 \\
\hline 3 & mu'ğam al-muhīt fí al- lūga $a^{h}$ & 168,870 & 66,763 & $39.54 \%$ & 6,411 \\
\hline 4 & kitābu al-'ayn & 141,098 & 54,970 & $38.96 \%$ & 5,826 \\
\hline 5 & al-mu'ğam al-wasìt & 112,164 & 45,614 & $40.67 \%$ & 6,489 \\
\hline 6 & al-muṣbāh al-munīr fi $\bar{g}$ garīb aš-šarh al-kabìr & 61,422 & 29,742 & $48.42 \%$ & 2,947 \\
\hline 7 & muḥtār aș-șịhāḥ & 40,295 & 17,636 & $43.77 \%$ & 3,420 \\
\hline 8 & $a l-m u g ̆ r a b$ fì tartīb al-mu 'rab & 39,930 & 13,798 & $34.56 \%$ & 2,322 \\
\hline
\end{tabular}

\subsection{Advanced Text Handling}

The TAL-Corpus implements advanced text handling tools which can automatically process linguistic information in a corpus and allow more sophisticated statistical analyses. Lexical database (i.e. the SALMA-ABCLexicon) was created using the extracted information from the TAL-Corpus text.

\subsubsection{Link to Lexical Database}

The TAL-Corpus was used to construct the SALMA-ABCLexicon. The SALMA-ABCLexicon is a lexical database that contains around three million word-root pairs. This lexical database was extracted from the text of the TAL-Corpus following the analyses steps as described in Section 3.2. These steps include (i) manually converting the traditional Arabic dictionaries' text into a unified format; (ii) a specialized algorithm extracts a bag of words from the definition part text of Arabic dictionaries where word-root pairs are stored; (iii) two linguistic rules were applied to the word-root pairs to verify that words are derived from the associated roots.

Later, a specialized program combines the disparate lexicon information into one large broad-coverage lexical resource the SALMA-ABCLexicon. A lexical information of a large dictionary called لعسان العرب lisān al-'rab 'Arab tongue' was feed to the program as a seed for the SALMA-ABCLexicon. All word-root pairs of the first dictionary were included in the SALMA-ABCLexion which represent around $48 \%$ of the total records. Around 82\% of the words and roots of المحيط في اللغة around 14\% of total records. تاج العروس من جواهر القاموس tağ al-'arūs min ğawāhir al-qāmūs dicitionary contributes $74 \%$ of its records which represents around $22 \%$ of the total records. The percentage of added records decreases during the combination process. This decrement indicates the termination of the combination process and which traditonal Arabic dictionaries are better to construct the morphological lexicon. Table [6] shows the traditional Arabic dictionaries that were used to construct the SALMA-ABCLexicon. It also shows the number of records and their percentage that contribute to the construction of the SALMA-ABCLexicon.

The SALMA-ABCLexicon contains 2774866 word-root pairs that represent 509506 different words and 261125 different non-vowelized words. It contains 12729 roots that are distributed into 12 biliteral roots; 8585 triliteral roots; 4038 quadriliteral roots; 63 quinqueliteral roots; and 31 different sexiliteral roots. The 509506 word types of the lexicon are distributed into; 117 word types derived from biliteral roots; 483356 word types of triliteral roots; 30873 word types of quadriliteral roots; 615 word types of quinqueliteral; and 335 word types of sexiliteral roots. Figure [8] shows the first 60 derived words of the root كتب k-t-b 'wrote'.

Table 6. Number of records extracted and inserted in the SALMA-ABCLexicon.

\begin{tabular}{|c|c|c|c|c|c|}
\hline \multirow[t]{2}{*}{$\#$} & \multirow[t]{2}{*}{ Lexicon } & \multirow{2}{*}{$\begin{array}{l}\text { Word } \\
{[B]}\end{array}$} & \multirow{2}{*}{$\begin{array}{l}\text { Records } \\
\text { inserted [A] }\end{array}$} & \multicolumn{2}{|c|}{ Percentage } \\
\hline & & & & $(\mathrm{A} / \mathrm{B}) \%$ & $(\mathrm{~A} / \mathrm{C}) \%$ \\
\hline 1 & lisānn al-'rab & 207,992 & 207,992 & $100.00 \%$ & $47.80 \%$ \\
\hline 2 & 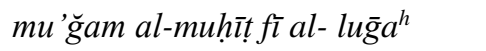 & 74,507 & 61,113 & $82.02 \%$ & $14.04 \%$ \\
\hline 3 & 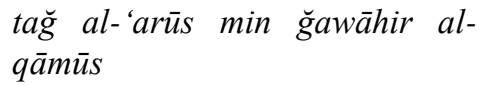 & 128,119 & 95,415 & $74.47 \%$ & $21.93 \%$ \\
\hline 4 & muhtāar aṣ-șiḥāh & 19,540 & 16,573 & $84.82 \%$ & $3.81 \%$ \\
\hline 5 & al-mй̆rib fì tartīb al-mu 'rib & 12,396 & 9,805 & $79.10 \%$ & $2.25 \%$ \\
\hline 6 & kitābu al- 'ayn & 30,292 & 18,878 & $62.32 \%$ & $4.34 \%$ \\
\hline \multirow[t]{2}{*}{7} & al-mu'ğam al-wasìt & 36,660 & 25,364 & $69.19 \%$ & $5.83 \%$ \\
\hline & Totals & 509,506 & $435,140[\mathrm{C}]$ & & \\
\hline
\end{tabular}

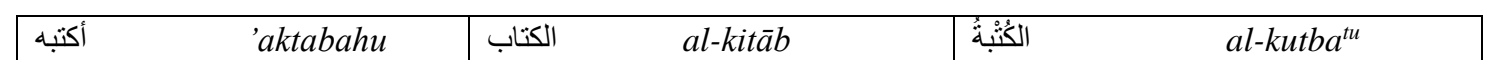




\begin{tabular}{|c|c|c|c|c|c|}
\hline أَكْتَبَ & 'aktaba & الكتابة & $a l-k i t \bar{a} b a^{t}$ & الكُكُنَةُةُ & $a l-k u t b a^{t u}$ \\
\hline أَكْنَبَبْتُ & 'aktabtu & الكتابةً & $a l-k i t a \bar{b} a^{t a}$ & الكِتاب & al-kitāb \\
\hline أَكْنْنِنِي & 'aktibnī & الكتابَة & al-kitāaba $a^{t}$ & الكِتابةُُ & $a l-k i t a \bar{b} a^{t u}$ \\
\hline إِكْتاباً & 'iktāb $b^{a n}$ & الكتاتيب & $a l-k a t a ̄ t \bar{b} b$ & الكِتابَ & al-kitāba \\
\hline استكتبه & 'istaktabahu & الكتبة & al-kitba ${ }^{t}$ & الكِتابَةُُ & $a l-k i t a \bar{b} a^{t u}$ \\
\hline اسنتْكَتَبَه & 'istaktabahu & الكتيبة & $a l-k a t \bar{\imath} b a^{t}$ & الكِتابُ & al-kitābu \\
\hline اسنتَكَتَبَها & 'istaktabahā & وكتيبة & wa katība ${ }^{t}$ & الكِتابِ & $a l-k i t a ̄ b i$ \\
\hline اكتتب & 'iktataba & الكَتائبَب & al-katā'iba & المكاتب & al-mukātib \\
\hline اكْتَتَبَ & 'iktataba & الكتَائبُبُ & al-katā'ibu & المكاتبة & $a l-m u k a ̄ t i b a^{t}$ \\
\hline اكْتَتَبَه & 'iktatabahu & الكتيبةُ & al-katībata & المكتب & al-maktab \\
\hline اكْتَبََها & 'iktatabahā & الكتَائبَ & al-katā'iba & المكتبة & al-maktaba ${ }^{t}$ \\
\hline اكتثُبْ & 'uktub & الكَتَبة & al-kataba ${ }^{t}$ & المكتوبة & $a l-m a k t \bar{u} b a^{t}$ \\
\hline اكَتْتِبْتَت & 'uktutibtu & الكَتبُبُ & $a l-k a t b u$ & الْكُنَّابُ & al-kuttābu \\
\hline اكْتِتابُك & 'iktitābuk & الكَتْبِ & $a l-k a t b i$ & الْأكِتَابَ & al-kitāba \\
\hline اكَتِتَابُتَكَ & 'iktitābuka & الكُتَبُ & al-kutabu & الْكِتَابَةُّ & $a l-k i t a \bar{b} a^{t u}$ \\
\hline الاكَتْتَبُ & al-'iktitābu & الكُتَتَبهُة & al-kutayba ${ }^{t u}$ & الأْكِنَابَةِة & $a l-k i t a \bar{b} a^{t i}$ \\
\hline التكاتب & at-takātubu & الكُتَّابَ & al-kuttāba & الَْكَكْتَبُ & al-maktabu \\
\hline الكاتب & $a l-k a ̄ t i b$ & الكُنَّابِ & al-kuttābi & الْمَكْتُوبَةُ & $a l-m a k t \bar{u} b a^{t u}$ \\
\hline الكاتِبُُ & al-kātibu & الكُتبة & al-kutba ${ }^{t}$ & إِسْنَكَنَبَبَ & 'istaktaba \\
\hline
\end{tabular}

Figure 8. The first 60 lexical entries of the root كتب $k$-t-b 'wrote' stored in the SALMA-ABCLexicon

\section{The TAL-Corpus Markup}

Markups are introduced to the TAL-Corpus to indicate its features such as lexicon name, lexical entry, and definitions of lexical entries. The TAL-Corpus is formatted using XML technology where lexicons are reformatted and their lexical entries are alphabetically arranged. All traditional Arabic lexicons that form the TAL-Corpus are stored using XML files. XML is a markup language that facilitates the labelling or tagging of corpus features. The use of XML allows formatting and labelling the features of the TAL-Corpus. Figure [9] shows the XML structure and the labels used to format the corpus files.

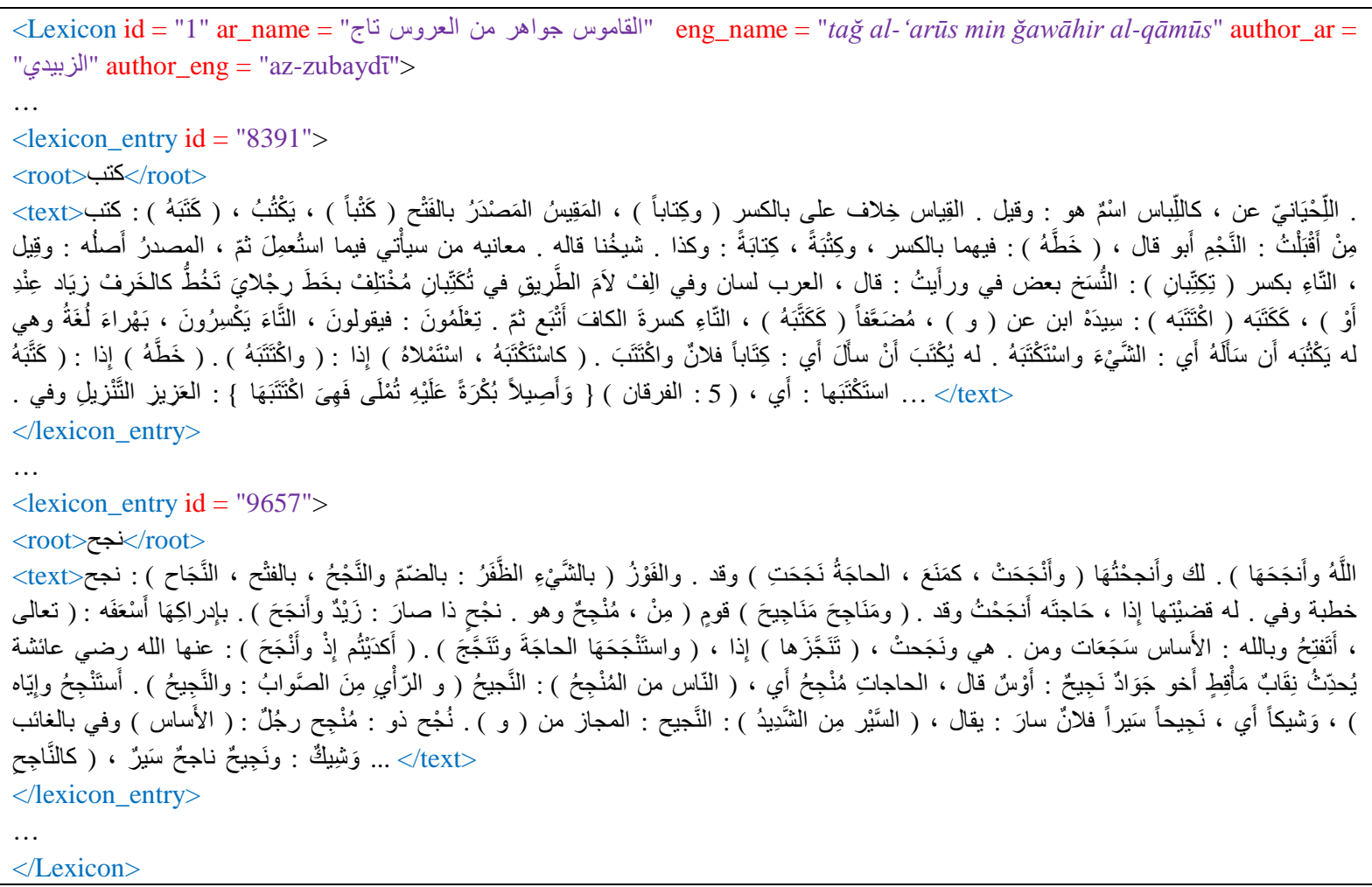

Figure 9. XML structure of The Corpus of Traditional Arabic Lexicons 


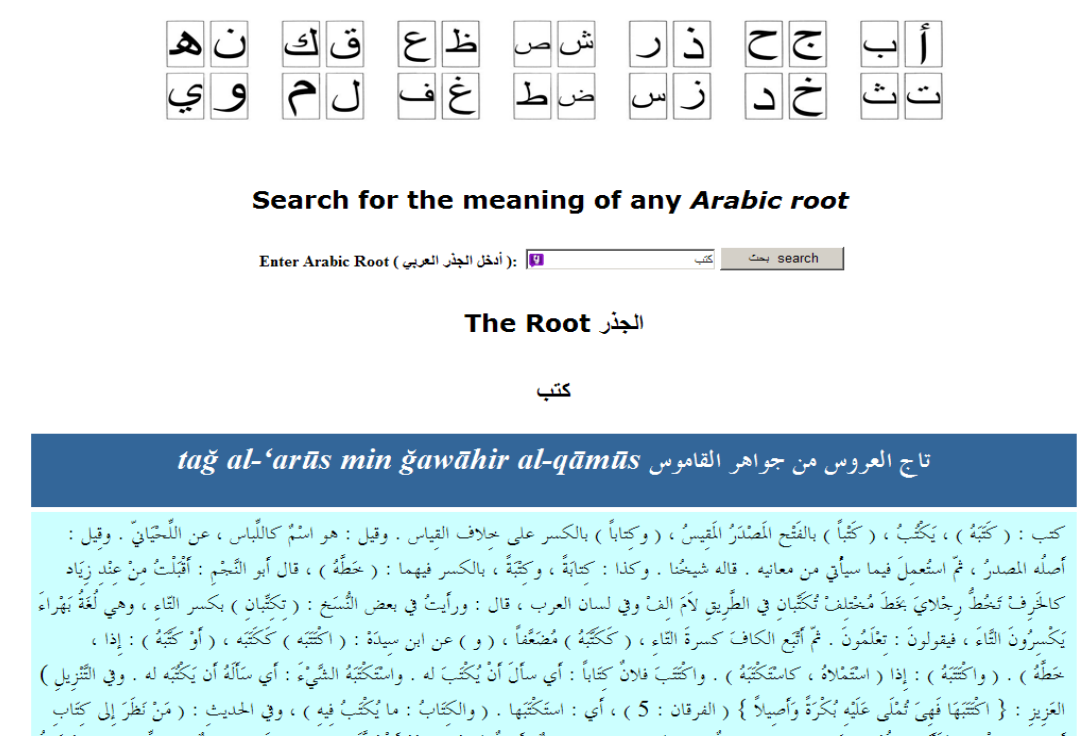

Figure 10. Web interface for searching the traditional Arabic dictionaries

These corpus markups were effectively used when a web interface ${ }^{2}$ for searching the contents of the corpus was developed. The web interface allows users to access the contents of the corpus, to search for a root and to retrieve the definition parts from the traditional Arabic lexicons included in the TAL-Corpus. Figure [10] shows part of the web interface for part of the results after searching for the root "كتب" $k$ - $t-b$.

\section{Evaluation}

The purpose of constructing the TAL-Corpus is to introduce a new lexicographic corpus that contains the majority of standard Arabic vocabulary. This kind of corpus will not only help in the design and development of Arabic monolingual dictionaries but also it can support constructing Computational Linguistics resources such as; morphological dictionaries, frequency lists, lexical and morphological databases, etc. The SALMA-ABCLexicon is a lexical and morphological dictionary that was constructed using the TAL-Corpus text (see Section 3.3.1). It contains slightly under three million word-root pairs.

There are no mature standard criteria for evaluating newly constructed text corpora (Atkins et al, 1992). Therefore, our criteria for evaluating the TAL-Corpus should meet the goal for construction. We need our corpus to include the majority of standard Arabic vocabulary. Moreover, these vocabularies should be diverse and cover contemporary as well as classical ones. Lexical diversity is defined by McArthy and Jarvis (2010) as "the range of different words used in a text, with a greater range indicating a higher diversity". Lexical diversity (LD) is computed as the token-type ratio. The lexical diversity of the TAL-Corpus scored 0.152 . It was evaluated by comparing it against the LD of rival Arabic corpora. The Arabic Web 2012 (arTenTen) corpus belongs to the TenTen corpora family which was created by harvesting web pages using SpiderLing. It contains around 7.5 billion tokens which represents around 2 million word types (Arts et al, 2014). Its LD scored about 0.000263. Similarly, the Arabic Internet Corpus was developed by harvesting articles from webpages published in Arabic. It contains around 165 million tokens and more than 4 million different tokens. Its LD is computed and scored 0.025965. The third corpus used in this comparative evaluation is the Arabic Wikipedia corpus (wiki-ar) ${ }^{3}$. It contains around 16 million tokens and slightly less than 1 million types. The LD for this corpus scored 0.057. Table [7] summarizes the LD for the 4 corpora used in the comparative evaluation. It shows that the LD of the TAL-Corpus scored the highest. Although it is similar size compared to the Arabic Wikipedia Corpus, its LD is 2.7 times higher. In comparison with large Arabic corpora namely: the Arabic Internet Corpus and the Arabic Web 2012 Corpus, although these large corpora contains large amounts of texts harvested from webpages, their LD is less in magnitude of times than the LD of the TAL-Corpus. 
Table 7. Comparative evaluation of the LD for four Arabic corpora

\begin{tabular}{lrcr}
\hline Corpus & \# tokens & \# Types & Lexical Diversity \\
\hline The TAL-Corpus & 14369570 & 2184315 & 0.152009 \\
Arabic Wikipedia Corpus (wiki-ar) & 16425960 & 0933895 & 0.056854 \\
Arabic Internet Corpus & 165674718 & 4301727 & 0.025965 \\
Arabic Web 2012 (arTenTen12) Corpus & 7464566176 & 1965566 & 0.000263 \\
\hline
\end{tabular}

Another criteria for evaluating the TAL-Corpus is based on the coverage of its vocabulary on different types of text corpora. The evaluation experiments were performed using the SALMA-ABCLexicon and three text corpora: the Qur'an, the Arabic Internet Corpus ${ }^{4}$, and the Corpus of Contemporary Arabic. The SALMA-ABCLexicon was used because it was constructed using the TAL-Corpus and it contains all the vocabulary instances from the TALCorpus. The three corpora were selected to represent different types of Arabic text. The Qur'an represents Classical Arabic; the Corpus of Contemporary Corpus represents Modern Standard Arabic; and a snapshot of current Arabic language on the web is represented by the Arabic Internet Corpus.

Two experiments were conducted to compute the coverage of the TAL-Corpus. The first experiment is based on exact matching of the non-vowelized words of the three corpora with the non-vowelized words of the SALMAABCLexicon. The results of this experiment scored a coverage of $67.53 \%$ for the Qur'an ${ }^{5} ; 65.58 \%$ for the Arabic Internet Corpus; and 67.5\% for the Corpus of Contemporary Arabic. Table [8] and Figure [11] show the results of the first coverage experiment. Some tokens are not words (i.e. Arabic words) but numbers, dates, currency symbols, punctuations, HTML or XML tags and English words. Only Arabic words were selected to compute the coverage of the SALMA-ABCLexicon.

Table 8 . The coverage of the lexicon using exact word-match method

\begin{tabular}{lllll}
\hline Corpus & Tokens & Arabic words & Covered words & Coverage \% \\
\hline Qur'an & 77800 & 77799 & 52536 & $67.53 \%$ \\
CCA & 684726 & 594664 & 389133 & $65.44 \%$ \\
Internet & 1128114 & 833916 & 546880 & $65.58 \%$ \\
\hline
\end{tabular}

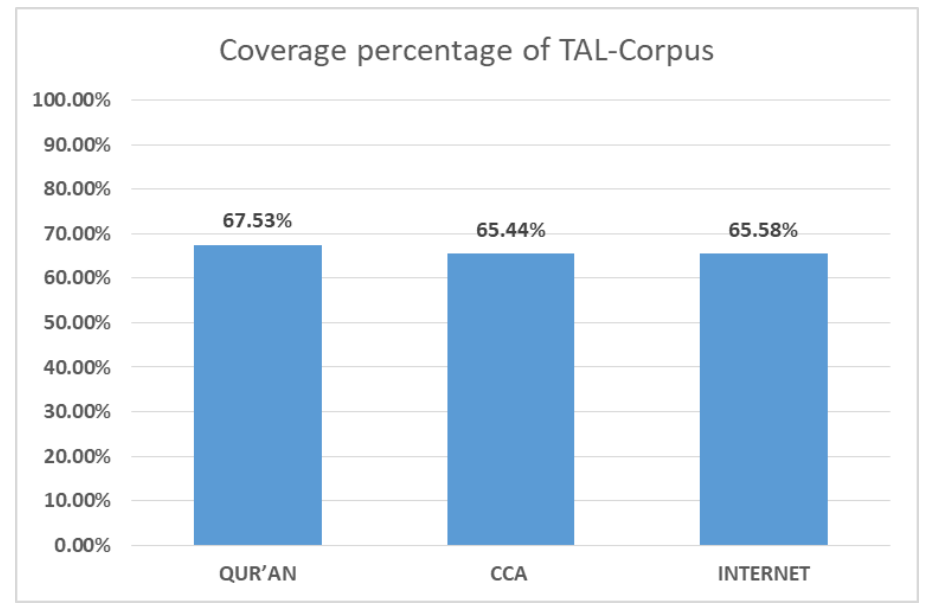

Figure 11. The coverage percentage of the TAL-Corpus using exact match method

Arabic is a morphologically rich language. Therefore, most Arabic words in context are complex words. Clitics and affixes are attached to the words in context which remarkably increase the various forms of words. Clitics make the matching process with lexical entries of the SALMA-ABCLexicon not an easy task. Hence, the coverage percentage would decrease. As an alternative, the coverage of the TAL-Corpus was computed by matching the lemmas of the SALMA-ABCLexicon with the lemmas of the three corpora. The SALMA-Lemmatizer (Sawalha, 2011) was used to lemmatize the three corpora and the lexical entries of the SALMA-ABCLexicon. The SALMALemmatizer also includes a list of function words. The other part of this experiment excludes function words from the coverage calculations. Tables [9] and [10] show the coverage percentage of the TAL-Corpus computed by matching lemmas including and excluding the function words respectively. Figure 12 shows a summary of the coverage of the TAL-Corpus based on matching lemmas. 
Table 9. Coverage of lemmas including function words

\begin{tabular}{lllll}
\hline Corpus & Tokens & Words & Covered words & Coverage \% \\
\hline Qur'an & 77804 & 77803 & 64065 & $82.34 \%$ \\
CCA & 685161 & 595099 & 507943 & $85.35 \%$ \\
Internet & 1128624 & 834426 & 708101 & $84.86 \%$ \\
\hline
\end{tabular}

Table 10. Coverage lemmas excluding function words

\begin{tabular}{lllll}
\hline Corpus & Tokens & Words & Covered words & Coverage \% \\
\hline Qur'an & 77804 & 54004 & 42532 & $78.76 \%$ \\
CCA & 685161 & 411482 & 338790 & $82.33 \%$ \\
Internet & 1128624 & 576407 & 476190 & $82.61 \%$ \\
\hline
\end{tabular}

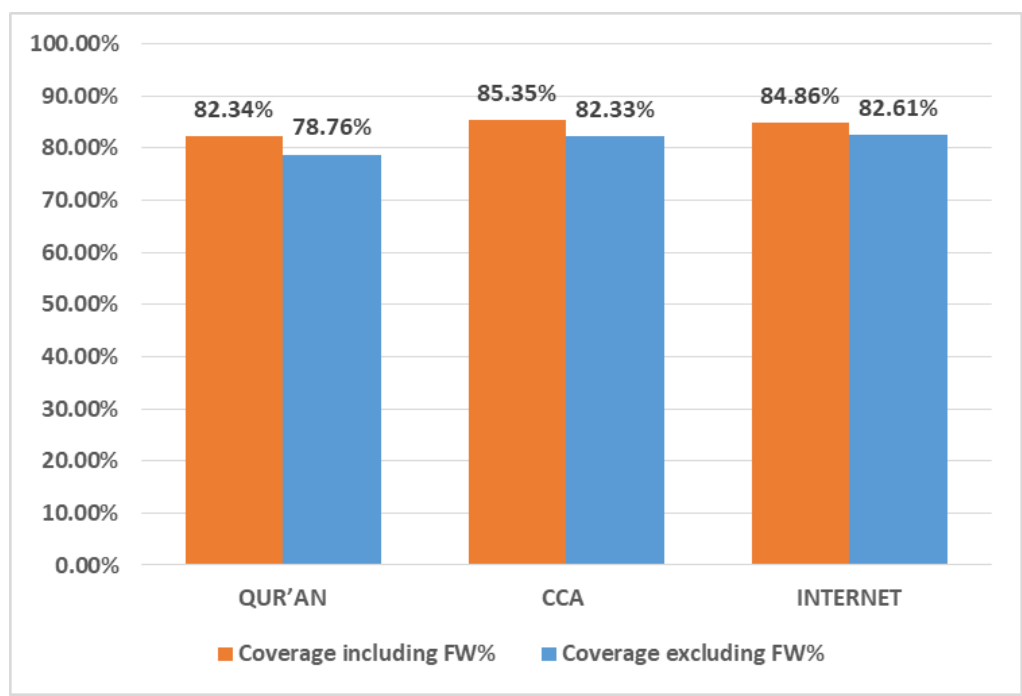

Figure 12. Coverage percentage of the TAL-Corpus using the lemmatizer

The average coverage percentage of the TAL-Corpus is $84.18 \%$ when matching the lemmas of the three corpora with the lemmas of the SALMA-ABCLexicon including function words. The coverage of the TAL-Corpus scored highest at $85.35 \%$ when computed using the CCA Corpus. The coverage scored $84.86 \%$ and $82.34 \%$ using the Internet corpus and the Qur'an respectively. The average coverage percentage of the TAL-Corpus is $81.23 \%$ after excluding function words. The highest coverage percentage was achieved using the Arabic Internet Corpus at $82.61 \%$. Similar coverage percentage at $82.33 \%$ was achieved using the CCA corpus. Finally, $78.76 \%$ was the coverage percentage scored when the Qur'an lemmas were matched excluding function words.

The evaluation experiments of the TAL-Corpus by computing its coverage against three Arabic corpora showed that it does not fully cover words that belong to the categories; (i) function words; (ii) new Arabic terms; (iii) relative nouns; and (iv) borrowed words. Function words such as إنَّهُ 'innahum "they are"; and التي allatī "which" were not covered in the TAL-Corpus. These words can be easily added by including traditional Arabic grammar books in the corpus (Diwan 2004). Second, new Arabic terms such

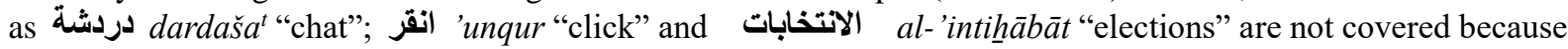
these words have appeared recently due to recent technical and social developments. Unfortunately, modern Arabic dictionaries are not available in machine readable format. Therefore, including these dictionaries in the TALCorpus requires retyping these dictionaries and reformating them in a machine readable format. Third, relative nouns الأسماء المنسوبة al-'asmä' al-mansūba ${ }^{h}$ are nouns that indicate affiliation of something to these nouns.

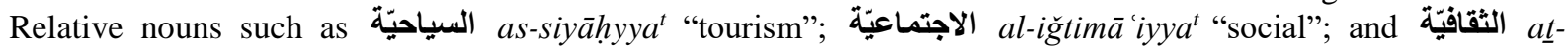
taqäfiyyat "cultural" have become widely used in the media and modern standard Arabic. Annexing this group of words to the TAL-Corpus can be achieved by including modern Arabic dictionaries. Fourth, borrowed words such as الألتور ad-duktūr "doctor"; الإيميل at-timayl "e-maillifūn "telephone"; and الإنترنت al-'intarnit "Internet" are foreign words transliterated into Arabic by using Arabic letters. Borrowed words are frequently found in newspaper and web pages text because of the lack of standard translations of them. However, Arabic 
Language Academies (i.e. organizations which are responsible for standardizing Arabic) are producing specialized dictionaries and word lists that translate these technical terms ${ }^{6}$ into Arabic. These specialized dictionaries can be included in the TAL-Corpus to increase its coverage. Figure [13] shows a sample of words which are not covered in the TAL-Corpus.

\begin{tabular}{|c|c|c|c|c|c|}
\hline ذَلَلَّدَ & $\underline{d}$ àlika & That & الاقتصادية & al-'iqtișādiyyat ${ }^{t}$ & Economical \\
\hline السَّمَاوَاتِ & Assamāwāti & Skies & الإنسان & al'insān & The human \\
\hline 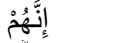 & 'innahum & They are & الإيميل & al-'īmayl & E-mail \\
\hline بِ بالَّلَّهِ & Billāhi & Swear to God & التليفون & at-tilifün & Telephone \\
\hline عَعْهُمُ & 'anhum & After them & الفلسطيني & al-filasțīn̄̄ & Palestinian \\
\hline بِالَكَقّْ & bilhaqqi & By the right & دردشة & dardaša $a^{t}$ & Chat \\
\hline 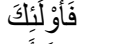 & fa'ulà'ika & And those & انقز & 'unqur & Click \\
\hline 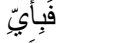 & fabi'ayyi & In what & الأمريكية & al-'amrīkiyya ${ }^{t}$ & American \\
\hline وَإِلَى لَى & $w a-' i l a \bar{~}$ & And to & الداخلية & ad-dāhniliyya $a^{t}$ & Interior \\
\hline فَسَوْفَ & Fasawfa & It will & الانتخابات & al-'intihāābāt & Elections \\
\hline 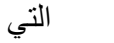 & Allatī & which & الو لايات & al-wilāyāt & States \\
\hline المتحدة & al-muttahidat ${ }^{t}$ & United & الاجتماعية & al-iğtimā iyyat & Social \\
\hline الدكتور & $a d-d u k t \bar{u} r$ & Doctor & الإلترنت & al-'intarnit & Internet \\
\hline السياحية & $a_{\text {s-siyāhiyyya }}^{t}$ & Tourism & التنمية & at-tanmiya $^{t}$ & Developmental \\
\hline الغربية & al-ḡarbiyyat ${ }^{t}$ & Western & الثقافية & $a \underline{t}-\underline{t} a q \bar{a} f i y y a^{t}$ & Cultural \\
\hline
\end{tabular}

Figure 13. A sample of common words which are not covered by the TAL-Corpus

\section{Potential Users and Uses}

The purpose for constructing the TAL-Corpus was to provide a collection of traditional Arabic dictionaries that can be analysed, studied and used to create comprehensive language resources such as; new Arabic dictionaries; frequency lists; collocates; morphological dictionaries, etc. Obviously, the potential users for the TAL-Corpus are lexicographers, Arabic linguists, language learners and computational linguists. The following is a discussion of potential uses of each expected user of this corpus.

- Lexicographers: This corpus was constructed as a resource for building new Arabic dictionaries. Therefore, lexicographers could use it to find examples of usage for words from different periods, track the changes in meaning of a certain vocabulary, and mark the origin of words and when they first appeared. The TAL-Corpus represents a bank of citations which are essential for the construction of new Arabic dictionaries. Citations denote objective evidence of language in use (Atkins and Rundell 2008).

- Arabic linguists: the TAL-Corpus provides the Arabic linguists with a repository of 23 traditional Arabic dictionaries. Feature labels (i.e. annotations (See Section 4) which were added to the corpus) make the search for a word, root, phrase or idiomatic expression easier via the corpus than paper based versions of traditional Arabic dictionaries. Arabic linguists are interested in studying the structures as well as the semantic features of words. The TAL-Corpus is an excellent resource for providing both. Word structures can be studied because roots and their derived words are provided. Semantic features of words such as the senses of the words; the changes to the meaning of the word; or new usage can be investigated and tracked using the TALCorpus. In addition, linguists can compare between the traditional Arabic dictionaries in terms of vocabulary size, ordering methodology and definitions of words. They also can conduct a comparison of other criteria such as features included in the dictionaries. These features can be the derived words, the different senses of words, phases, idioms and examples of usage.

- $\quad$ Language learners: Arabic language learners of both native and nonnative speakers use Arabic dictionaries mainly to search for words' meanings. Searching traditional Arabic dictionaries, where roots are the lexical entries, is not easy as it requires learners to know the root of the words. The TAL-Corpus provides a collection of 23 traditional Arabic dictionaries which were annotated to facilitate searching for definitions of either a word or a root. Learner can search for a word and retrieve the definition of it in addition to other linguistic information such root, lemma, derived words of the same root or lemma, examples of usage, phrases and idioms.

- Computational linguists: Corpora are essentially used by computational linguists to build language models for machine learning algorithms. The TAL-Corpus could be used to build language models for Arabic morphological analysers, stemmers and lemmatizers. As well as, language models for sematic analysis can 
be built for Arabic using the TAL-Corpus. Computational linguists can build tracking programs that investigate the development of Arabic vocabulary and the changes of their meanings. The TAL-Corpus includes traditional Arabic dictionaries of a period that span more than 1200 years which enables tracking the development and changes of meaning for Arabic vocabulary. In conclusion, the TAL-Corpus is an essential resource for extracting useful information that supports a wide verity of Arabic NLP applications such as; root extraction applications, morphological analysers, semantic networks of Arabic vocabulary, WordNets, ontologies ... etc.

\section{Discussion of the Results, Limitations and Improvement}

The TAL-Corpus is constructed using text from traditional Arabic dictionaries. It is characterized by a wide coverage of Arabic words, word types and roots. The evaluation proved that the TAL-Corpus has a wide coverage of about $85 \%$ of the test corpora words. Despite the time span of 13 centuries of the traditional Arabic lexicons from which the TAL-Corpus has been derived, only 15\% of the test corpora words were not captured. The latest Arabic dictionary included in the TAL-Corpus is المعجم الوسيط al-mu '̆gam al-wasìt which appeared in 1960s. Hence, new vocabulary items added to Arabic in the past 50 years are not covered in the TAL-Corpus. Moreover, due to the advances in telecommunication and information technology; globalization; and the wide and intensive use of social networks, words of foreign languages have been increasingly used in both spoken and written Arabic. These foreign words do not have a proper translation into Arabic, but are written using Arabic letters (i.e. transliterated). Advances in telecommunication and information technology imply new products with their original names have entered Arab countries. These products keep their original names which have been widely used and become part of the contemporary Arabic vocabulary. Moreover, the use of dialectical Arabic has increased in the written and spoken forms due to open systems such as chat rooms, blogs and forums, and social networks which allow people to write text without restrictions.

The TAL-Corpus was used to construct a broad-coverage morphological database the SALMA-ABCLexicon. This database did not involve any manual correction due to the limitations in funding. However, an automatic correction and verification procedure was applied to part of the database. The verification procedure was performed by counting how many times the word-root pairs appear in the analyzed traditional Arabic dictionaries. 976427 wordroot pairs representing $35.19 \%$ of the lexicon's word-root pairs scored a count of 2 or more. This means that these word-root pairs appeared in different dictionaries. Therefore, these word-root pairs have a high potential to be valid and correct.

This is the first version of the SALMA-ABCLexicon. It can be extended to include the full morphological analyses of the lexical entries and other useful information that will enhance the performance of NLP applications. Special linguistic lists such as compounds, collocations, idiomatic phrases, phrasal verbs and named entities can be added to extend the lexicon. Moreover, morphological lists such as broken plurals, intransitive and transitive verbs, rational and irrational words and primitive nouns can be another extension to the lexicon. The SALMAABCLexicon can also be extended by adding modern and dialect vocabularies from newly constructed Arabic corpora and the web.

\section{Conclusions}

The Corpus of Traditional Arabic Lexicons (the TAL-Corpus) is a special corpus which is constructed from the text of 23 traditional Arabic dictionaries. These dictionaries are spanning over a period of 1200 years. The corpus contains 14369570 words and 2184315 word types. The motivation for building the TAL-Corpus is to collect and organize well-established and long traditions of traditional Arabic lexicons. The TAL-Corpus can also be used to construct new corpus-based Arabic dictionaries. Corpora were not used to construct Arabic dictionaries and lexical databases yet. Therefore, building corpora for the purpose of building new Arabic dictionaries is needed.

Thousands of traditional Arabic dictionaries were constructed in the past 1200 years. These dictionaries are different size, type and ordering of their lexical entries. The wide variety of traditional Arabic dictionaries represent rich base for building a corpus that can be further used and exploit to construct new corpus-based Arabic dictionary.

The TAL-Corpus followed standard design and development criteria that informed major decisions in corpus creation. The text of the TAL-Corpus is composed from the text of 23 freely available and machine readable traditional Arabic dictionaries. These dictionaries were processed to have a unified format. The unified format is based on arranging the contents of the corpus by roots (i.e. the head words for the majority of traditional Arabic dictionaries) and their definitions. Then, the SALMA-root extractor and lemmatizer were used to tokenize, strip diacritics, and extract roots and lemmas for each word in the corpus. Frequency lists of both vowelized and nonvowelized word were also generated. 
The SALMA-ABCLexicon is constructed by analysing the TAL-Corpus text. The processing steps in constructing the SALMA-ABCLexicon involve; applying linguistic rules that were encoded in a specialized program to extract the root and the words derived from that root. Second, a combination algorithm merges the information extracted from the previous step into one large broad-coverage lexical database. The SALMA-ABCLexicon contains 2781 796 vowelized word-root pairs which represent 509506 different non-vowelized words.

The TAL-Corpus is stored and distributed using XML technology. The corpus XML files contain all markups which indicate the corpus features. The choice of using XML technology is to facilitate the distribution and the use of the corpus. The TAL-Corpus is an open-source resource which is licenced under a Creative Commons Attribution-NonCommercial 4.0 International Licence.

The evaluation of the TAL-Corpus was done by computing its coverage over three Arabic corpora; the Corpus of the Contemporary Arabic; the Qur'an text; and the Arabic Internet Corpus. The coverage was computed by matching the words of the test corpora to the words in the SALMA-ABCLexicon, which scored about $67 \%$. A lemmatizer program was used to compute the coverage by matching the lemmas of the test corpora and the lemmas of the SALMA-ABCLexicon. This method scored a coverage of about $82 \%$.

The potential users for the TAL-Corpus are lexicographers, Arabic linguists, language learners and computational linguists. The potential practices for TAL-Corpus are to provide a collection of traditional Arabic dictionaries that can be analysed, studied and used to create comprehensive language resources such as; new Arabic dictionaries; frequency lists; collocates; morphological dictionaries, etc.

\section{References}

Abbas, M., \& Smaili, K. (2005) Comparison of Topic Identification Methods for Arabic Language, RANLP05 : Recent Advances in Natural Language Processing, pp. 14-17, 21-23 September 2005, Borovets, Bulgary.

Abbas, M., Smaili, K., \& Berkani, D. (2011) Evaluation of Topic Identification Methods on Arabic Corpora, Journal Of Digital Information Management, 9(5), 185-192.

Al-Sulaiti, L., \& Atwell, E. (2006). The design of a corpus of contemporary Arabic. International Journal of Corpus Linguistics, 11(2), Jan 2006, p. 135-171. https://doi.org/10.1075/ijcl.11.2.02als

Al-Thubaity, A., Khan, M., Al-Mazrua, M., \& Al-Mousa, M. (2013). New Language Resources for Arabic: Corpus Containing More Than Two Million Words and a Corpus Processing Tool. In Proceedings of the Asian Language Processing (IALP) Conference, pp.67-70. https://doi.org/10.1109/IALP.2013.21

Alansary, S., \& Nagi, M. (2014) The International Corpus of Arabic: Compilation, Analysis and Evaluation. In Proceedings of the EMNLP 2014 Workshop on Arabic Natural Language Processing (ANLP), 8-17, October 25, 2014, Doha, Qatar.

AlMaayah, M., Sawalha, M., \& Abushariah, M. (2016) Towards an automatic extraction of synonyms for Quranic Arabic WordNet. Int J Speech Technol, 19, 177. https://doi.org/10.1007/s10772-015-9301-9

Alrabiah, M., Al-Salman, A. \& Atwell, E. (2013). The design and construction of the 50 million words KSUCCA King Saud University Corpus of Classical Arabic. In Proceedings of the Second Workshop on Arabic Corpus Linguistics (WACL-2), 22 Jul. 2013, Lancaster University, UK.

Arts, T. (2014). The Making of a Large English-Arabic/Arabic-English Dictionary: the Oxford Arabic Dictionary. In Proceedings of XVI EURALEX International Congress: The User in Focus, 15-19 July 2014, Bolzano/Bozen.

Arts, T., \& McNell, K. (2013) Corpus-based lexicography in a language with a long lexicographical tradition: The case of Arabic. In Proceedings of Second Workshop on Arabic Corpus Linguistics (WACL-2), Workshop in conjunction with the Corpus Linguistics 2013 conference, Monday 22nd July 2013 - Lancaster University, UK.

Arts, T., Belinkov, Y., Habash, N., Kilgarriff, A., \& Suchomel, V. (2014). arTenTen: Arabic Corpus and Word Sketches. Journal of King Saud University-Computer and Information Sciences, 26(4), 357-371. https://doi.org/10.1016/j.jksuci.2014.06.009

Atkins, S., \& Rundell, M. (2008). The Oxford guide to practical lexicography Oxford; New York; Oxford University Press.

Atkins, S., Clear, J., \& Ostler, N. (1992) Corpus Design Criteria. Lit Linguist Computing, 7(1), 1-16. https://doi.org/10.1093/llc/7.1.1

Attia, M., \& van Genabith, J. (2013). A Jellyfish Dictionary for Arabic. Retrieved Nov., 1, 2017, from 
https://www.researchgate.net/publication/259494599_A_Jellyfish_Dictionary_for_Arabic

Black, W. J., \& ElKateb, S. (2004). A Prototype English-Arabic Dictionary Based on WordNet. The Second Global Wordnet Conference 2004 Brno, Czech Republic, January 20-23, 2004, 67-74. Retrieved from http://www.fi.muni.cz/gwc2004/proc/95.pdf

Buckwalter, T. (2004). Buckwalter Arabic Morphological Analyzer Version 2.0: Linguistic Data Consortium, catalog number LDC2004L02 and ISBN 1-58563-324-0.

Boudelaa, S., \& Marslen-Wilson, W. D. (2010). Aralex: A lexical database for Modern Standard Arabic. Behavior Research Methods, 42(2), 481-487. https://doi.org/10.3758/BRM.42.2.48

Diwan, A. H. (2004). المجم النحوي لدفردات اللغة العربية The Syntactic Lexicon of Arabic Words (First edition). Aleppo, Syria: Fusselat Publishers.

Elkateb, S., Black, W. J., \& Farwell, D. (2006). Arabic WordNet and the Challenges of Arabic. In Proceedings of The Challenge of Arabic for NLP/MT International Conference at The British Computer Society (BCS), London.

Elkateb, S., \& Black, W. J. (2001). Towards the Design of English-Arabic Terminological Knowledge Base. Paper presented at the Proceedings of ACL 2000, Toulouse, France:113-118.

Eynde, V. E., \& Gibbon, D. (Eds.). (2000). Lexicon development for speech and language processing. Dordrecht, The Netherlands: Kluwer Academic Publishers.

Ghazali, S., \& Braham, A. (2001). Dictionary Definitions and Corpus-Based Evidence in Modern Standard Arabic. Arabic NLP Workshop at ACL/EACL. Toulouse, France.

Hoogland, J. (1996). The use of OCR software for Arabic in order to create a text corpus of Modern Standard Arabic for lexicographic purposes. In A. Ubaydli (Ed.), Proceedings of the international conference and exhibition on multi-lingual computing (pp. 2701-2716). Cambridge University.

Ismail, O., Yagi, S., \& Hammo, B. (2014). Corpus Linguistic Tools for Historical Semantics in Arabic. International Journal of Arabic-English Studies (IJAES) 15, 135-152.

Khalil, H. (1998). Dirasat fi al-lughah wa al-ma'ajim " دراسات في اللغة والمعاجم " Studies of language and lexicons (First Edition ed.). Beirut, Lebanon: Dar al-nahdhah al-arabiah.

Mousser, J. (2010). A Large Coverage Verb Taxonomy for Arabic. In Proceedings of the Seventh conference on Language Resources and Evaluation (LREC'10), Valletta, Malta.

Ooi, Vincent B. Y. (1998). Computer corpus lexicography Edinburgh: Edinburgh University Press.

Oxford Dictionaries. (2017) The Oxford English Corpus, Retrieved Nov., 1, 2017, from https://en.oxforddictionaries.com/explore/oxford-english-corpus

Rodríguez, H., Farwell, D., Farreres, J., Bertran, M., Alkhalifa, M., \& Martí, M. (2008). Arabic WordNet: Semiautomatic Extensions using Bayesian Inference. In proceedings of the $6^{\text {th }}$ Conference on Language Resources and Evaluation LREC2008, Marrakech (Morocco). Retrieved from http://www.lsi.upc.edu/ nlp/papers/rodriguez08b.pdf

Saad, M., \& Ashour, W. (2010), OSAC: Open Source Arabic Corpora, in 'EEECS'10 the 6th International Symposium on Electrical and Electronics Engineering and Computer Science' , European University of Lefke, Cyprus, 118-123.

Sawalha, M. (2011). Open-source Resources and Standards for Arabic Word Structure Analysis. (PhD), University of Leeds, Leeds.

Sawalha, M., \& Atwell, E. (2010). Constructing and Using Broad-Coverage Lexical Resource for Enhancing Morphological Analysis of Arabic. in: Proceedings of the Language Resource and Evaluation Conference LREC 2010, 17-23 May 2010, Valleta, Malta.

van Mol, M., \& Paulussen, H. (2001). AraLat: a relational database for the development of bi-lingual Arabic dictionaries. In S. Lee (Ed.), Proceedings of Asialex 2001, Asian Bilingual-ism and the Dictionary (pp. 206211). Seoul, August 2001.

van Mol, M. (2000). The development of a new learner's dictionary for Modern Standard Arabic: the linguistic corpus approach. In U. Heid, S. Evert, E. Lehmann \& C. Rohrer (Eds.), Proceedings of the ninth EURALEX International Congress (pp. 831-836). Stutt-gart, 8-12 August. 
Zaghouani, W. (2014) Critical Survey of the Freely Available Arabic Corpora, Workshop on Free/Open-Source Arabic Corpora and Corpora Processing Tools, LREC'14 workshop, Reykjavik, Iceland.

Zarrouki, T., \& Kebdani, M. (2009). مشروع أية -سبل القاموس العربي للتدقيق الإملائي مفتوح المصدر، تجربة وآفاق Aya-Spell Project, An Open-source Arabic Spell Checker Dictionary, experience and Future Work. Proceedings of the workshop of morphological analyzer experts for Arabic language, organized by Arab League Educational, Cultural and Scientific Organization (ALECSO), King Abdul-Aziz City of Technology ( KACT) and Arabic Language Academy., Damascus - Syria.

Zarrouki, T., \& Balla, A. (2009). Implementation of infixes and circumfixes in the spellcheckers. 2nd International Conference on Arabic Language Resources and Tools, Cairo - Egypt.

Zemanek, P. (2001). Clara (Corpus Linguae Arabicae): An Overview. In ELSNET (Ed.), Proceedings of ACL/EACL workshop on Arabic language processing. Toulouse, France.

\section{Notes}

Note 1. شبكة مشكاة الإسلامية Meshkat Islamic Network http://www.almeshkat.net

Note 2. A web interface for searching the traditional Arabic lexicons for a certain root http://www.comp.leeds.ac.uk/cgi-bin/scmss/arabic_roots.py

Note 3. Frequency list of the Arabic Wikipedia corpus (wiki-ar) is found on http://corpus.leeds.ac.uk/frqc/wikiar.num

Note 4. Leeds collection of Internet corpora: Arabic Internet Corpus http://corpus.leeds.ac.uk/internet.html

Note 5. The text of the Qur'an used in this experiment was represented in MSA script.

Note 6. Jordanian Arabic Language Academy: Word lists of technical terms http://www.majma.org.jo/?cat=53

\section{Copyrights}

Copyright for this article is retained by the author(s), with first publication rights granted to the journal.

This is an open-access article distributed under the terms and conditions of the Creative Commons Attribution license (http://creativecommons.org/licenses/by/4.0/). 